WIDER Working Paper 2014/006

Minimum wage and informality in Ecuador

Carla Canelas*

January 2014 
Abstract: This paper investigates if changes in the minimum wage have influenced changes on the formality and informality rates, and the level of wages in Ecuador. A 12-year panel was built. It allows to overcome the short time span of household data and so to characterize changes over time. Results suggest that the minimum wage has virtually no effect on employment and wages. The high level of non-compliance, and the important share of informal workers call for new policies and institutions concerned with the enforcement of labor regulations and design of social security systems and laws that protect informal workers.

Keywords: labor markets, informality, minimum wage

JEL classification: J21, J23, J3

Acknowledgements: This paper is the result of work done during a research internship at UNU-WIDER. The author thanks François Gardes, Philip Merrigan, and Miguel Niño-Zarazúa for useful discussions and comments.

*Paris School of Economics, carla.canelas@malix.univ-paris1.fr

This study has been prepared within the UNU-WIDER project 'New Directions in Development Economics'.

Copyright (C) UNU-WIDER 2014

ISSN 1798-7237 ISBN 978-92-9230-727-1

Typescript prepared by author, processed by Lorraine Telfer-Taivainen at UNU-WIDER.

UNU-WIDER gratefully acknowledges the financial contributions to the research programme from the governments of Denmark, Finland, Sweden, and the United Kingdom.

The World Institute for Development Economics Research (WIDER) was established by the United Nations University (UNU) as its first research and training centre and started work in Helsinki, Finland in 1985. The Institute undertakes applied research and policy analysis on structural changes affecting the developing and transitional economies, provides a forum for the advocacy of policies leading to robust, equitable and environmentally sustainable growth, and promotes capacity strengthening and training in the field of economic and social policy-making. Work is carried out by staff researchers and visiting scholars in Helsinki and through networks of collaborating scholars and institutions around the world.

UNU-WIDER, Katajanokanlaituri 6 B, 00160 Helsinki, Finland, wider.unu.edu

The views expressed in this publication are those of the author(s). Publication does not imply endorsement by the Institute or the United Nations University, nor by the programme/project sponsors, of any of the views expressed. 


\title{
Minimum Wage and Informality in Ecuador*
}

\author{
Carla Canelas ${ }^{\dagger}$
}

\begin{abstract}
This article investigates if changes in the minimum wage have influenced changes on the formality and informality rates, and the level of wages in Ecuador. A 12 years panel was built. It allows to overcome the short time span of household data and so to characterize changes over time. Results suggest that the minimum wage has virtually no effect on employment and wages. The high level of noncompliance, and the important share of informal workers call for new policies and institutions concerned with the enforcement of labor regulations and design of social security systems and laws that protect informal workers.
\end{abstract}

Keywords: labor markets; informality; minimum wage.

JEL Classification: J21, J23, J3

\section{Introduction}

Minimum wages are intended to leak workers out of poverty, reduce inequality and exploitation. Weather they are an effective instrument to achieve these goals has for long been debated, but a common consensus has not been found.

*This paper is the result of the work done during a research internship at UNU-WIDER. The author thanks François Gardes, Philip Merrigan, and Miguel Niño-Zarazúa for useful discussions and comments.

${ }^{\dagger}$ Paris School of Economics, Université Paris 1 Panthéon Sorbonne, Centre d'Economie de la Sorbonne, 106-112 Bd de l'Hôpital, 75013 Paris, France. e-mail address: carla.canelas@malix.univ-paris1.fr 
On the one hand, neoclassical theory predicts negative effects on employment and an increase in averages wages as direct consequences of rising the minimum wage. The standard two-sector model, one covered and one uncovered, dictates that raising the minimum wage reduces employment in the covered sector, creates unemployment, and eventually push the workers to find employment in the uncovered sector which in turn has a negative effect on the lower tail of the wage distribution.

On the other hand, empirical findings are ambiguous. While the results from the first wave of studies of the minimum wage go in line with what is expected from traditional theory, most recent literature has found small disemployment effects and positive wage effects.

Evidence from Latin America is limited, even though the diversity of minimum wages and legislations in the region, provide a good environment to study its effects on the labor market. Moreover, the significant size of the informal (uncovered) sector, $60-80$ per cent of the working population, highlight the importance of research focused on this sector of the labor market, and the need of new policies and institutions concerned with the enforcement of labor regulations, and the design of social security systems and laws that protect informal workers.

The case of Ecuador is particularly interesting in terms of economic policy. During 1998/99 Ecuador went through an important macroeconomic and financial crisis that had dramatic effects especially in rural areas in the Coast Region hurt by El Niño, and among middle-class households. The crisis and its negative effects on GDP and inflation resulted in the adoption of the US dollar in September 2000. Inequality is high, the Gini coefficient is 0.49 , and poverty is widespread. Around 15 per cent of the population lives under the official extreme poverty line, and around 30 per cent under the official poverty line. The Ecuadorian labor market is characterized by widespread informality that attains almost 80 per cent of the working population. Moreover, despite several increases of the legal minimum wage during the last decade, the proportions of formal and informal workers in the labor market seem to remain constant.

This article studies the relationship between minimum wage and employment. In particular it investigates whether or not, and if so, to what extent changes in the minimum wage influence changes on the formality and informality rates, and the level of wages. In 
order to measure the sensitivity of the results, the models are re-estimated for alternative definitions of informality.

This study contributes to the existing literature in two ways. First, a 12-year synthetic panel is built. It allows to overcome the very short time span of available household-level data for Ecuador and so to characterize changes in labor informality over time. Second, it enriches the very limited evidence that exists for this country. In this regard, Latin America and the Caribbean have few empirical studies measuring the impact of policy instruments, such as the minimum wage, on the labor market. Almost all the research has been focused on developed countries, and in the case of the LAC region, on Brazil and in a fewer extend on Mexico and Colombia.

The rest of the paper is organized as follows: Section 2 provides a quick summary of the main theories regarding the introduction of a minimum wage. Section 3 reviews the literature. Section 4 gives an overview of the minimum wage in Ecuador. Section 5 presents the data and descriptive statistics. Section 6 discusses the methodology. Section 7 presents the results and concludes.

\section{Theoretical framework}

The neoclassical one sector model is based on complete coverage, competitive markets, and homogenous workers. In this setting, the equilibrium market wage is given by the marginal product paid to the each worker. If a binding minimum wage is introduced, average wages will increase but some workers will lose their jobs, increasing the unemployment rate. Even thought, the model provides a guide for what can be expected after the imposition of a wage floor, the assumptions in which it is based, are strong and certainly far from the reality of most Latin American countries. The following models relax these assumption and present a more appropriate representation of the labor markets, even though it is still far from reality.

The traditional two-sectors model with unemployment considers a covered sector (formal) and a uncovered sector (informal) in the labor market segmented by wage rigidities, such as the minimum wage. After setting a wage floor above the equilibrium market wage, wages in the formal sector will increase, but those formal workers with a marginal product 
below the new minimum wage will lose their jobs. This displacement of workers from the formal sector will be absorbed by employment on the informal sector and unemployment. Displaced workers in the uncovered sector will pull down the informal sector wage due to an increase on the labor supply.

The global results are employment destruction and increase in wages in the formal sector, and increase in employment and decrease on wages in the informal one. The magnitude of effects depends then, on the elasticity of labor demand and the effectiveness of the minimum wage.

Among the most studied two sector-models with unemployment are those proposed by Harris and Todaro [1970] and Mincer [1976]. Even though, they have a different framework and are based on different assumptions, they all lead to similar results.

A different setting is that of Monopsony. The idea here is that firms have some power on the labor market and so they fix a non-competitive wage below the equilibrium market wage, given by the point where marginal revenue equals marginal cost. If the minimum wage is set between this non-competitive wage and the equilibrium market wage, employment and the level of wages will increase. If the minimum wage is set outside these boundaries, no effects or unemployment effects are expected.

\section{Literature review}

The effects of the minimum wage on the labor market have been thoroughly studied during the last decades, but not common consensus has been found. In spite of this, empirical literature can be divided in two main branches.

The first one, in line with neoclassical theory, finds positive effects on wages and negative employment effects, see for instance Brown et al. [1982], who provides an extensive survey for the US literature before the 80's where the common consensus was that a 10 per cent increase in minimum wage leads to a decrease in teenage employment ${ }^{1}$ of 1 to

\footnotetext{
${ }^{1}$ In most developed countries teenagers are an important fraction of minimum wage earners, from there the interest to study the effects of changes in the minimum wage in this group. The case of Latin America is different, since adults are a significative proportion of minimum wage earners, and by far the most important one.
} 
3 per cent. For a most recent literature see Burkhauser et al. [2000], Deere et al. [1995], Neumark and Wascher [1992], and Maloney and Nuñez Mendez [2003].

The second branch concerns studies where minimum wage has little (clustered around zero) or no effect on employment, and positive effects on the wage distribution, which contradicts the conventional model. See the works of Card [1992], Katz and Krueger [1992], Card and Krueger [1994], Dolado et al. [1996], Dickens et al. [1999], Lemos [2004], Dickens and Manning [2004].

Evidence for Latin America is limited. Most empirical studies use data from the USA and in a fewer extend from european developed countries. The few studies on Latin America are in turn concentrated in Brazil, and some in Mexico, Colombia, and Costa Rica. Findings are diverse, for instance Bell [1997] found no disemployment effects for Mexico and negative employment effects for Colombia. Maloney and Nuñez Mendez [2003] also found negative employment effects for the Colombian case. On the other hand, the recent work of Bosch and Manacorda [2010] reveals that the increasing inequality on the wage distribution of Mexican workers is due to the important deterioration of the real minimum wage between 1980 and 1990. The works of Neri et al. [1998], Fajnzylber [2001], and Lemos [2004] among others contribute to the brazilian literature. The common consensus among these studies is that in Brazil the minimum wage has large positive wage effects and small unemployment effects, acting as an effective tool for redistribution. Brazilian literature is also important to the extend that the 'effeito farol' (lighthouse effect) seems to be a common characteristic of the country's labor market, where informal workers's wages are positively affected by increases on the minimum wage, suggesting that the official wage floor serves a reference wage for the uncovered sector where labor market legislation, by definition, does not apply. The case of Costa Rica, Gindling and Terrell [2005] found that the minimum wage raises wages of workers in the formal and informal sector, and that it also reduces wages differentials between the larger and smaller firms, although it does not have a significant impact on wages of the self-employed.

The evidence for Ecuador is scarce, the few studies on the country focus on the effects on the wage distribution and not in employment effects. MacIsaac and Rama [1997] studied the determinants of hourly earnings in the country, and found that an increase of labor costs due to labor market regulations is smaller than expected. Moreover, the effect of 
mandated benefits on earning is drastically attenuated by the low level and weak enforcement of the minimum wage. Cunningham and Kristensen [2006] studied the impact of the minimum wage on the distribution of wages in a group of 19 LAC countries. The results obtained for Ecuador, from the 1998 labor force survey, show not clear pattern regarding the impact of the minimum wage on the wage distribution of the formal sector workers.

\section{Minimum wage in Ecuador}

The minimum wages in Ecuador are set by sector and occupation. In 2013, there exist 22 sectorial commissions in charge of fixing the wages for each brunch of occupation within each sector.

A national minimum wage is set by the National Council of Salaries (CONADES) which acts as the floor for all sectorial wages. No worker can be paid less than the national minimum wage. Since the sectorial wages fixed by Sectorial Councils do not differ significantly from the national minimum wage (specially for the lower categories, majority of the labor force), and given that data limitations do not allow us to clearly identify the specific occupation of each worker, the national minimum wage is used for all the estimations in the present study.

The CONADES is formed by a tripartite committee, with one representative of the Government, one of the private sector, and one of the workers. In case of non-agreement between the parties, the minimum wage is set by the Government. Historically, this has been the case since non consensus has been found between the representatives of the employers and the employees during the meetings.

\subsection{Identification}

Variation in minimum wage is critical for the correct identification of its effects on the wage distribution and employment rate of a country's labor force. When the minimum wage is set at national level, as it is in Ecuador, cross sectional variation does not exist. In order to deal with this problem one can use different variables as proxies of the minimum wages, such as 'fraction at' defined as the fraction of workers earning the minimum 
wage or close to it, $0.9 \cdot m w \leq w a g e \leq 1.1 \cdot m w^{2}$, 'fraction below' defined as the fraction of workers earning below the minimum wage, wage $\leq 0.9 \cdot \mathrm{mw}$, or 'fraction affected' defined as the fraction of workers earning between the old and the new minimum wage, $m w_{t-1} \leq w a g e_{t-1} \leq m w_{t}$. This group of variables is known in the literature as Degree of Impact Measures, see Card [1992], Dolado et al. [1996], and Brown [1999]. The name accounts for the fact that they are focused on the fraction of workers directly affected by changes in the minimum wage. Across provinces, this fraction differs, and so cross sectional variation can be recovered. Figure 16 in the Appendix, plots the evolution of the fraction of workers earning near de minimum wage by province. As discussed by Lemos [2004] 'fraction at' is a measure of the effectiveness of the minimum wage increase, 'fraction below' of the noncompliance with the increase, and 'fraction affected' of the potential effect of the increase. Since they focus on different fraction of workers, these variables are not always directly comparable, so in this article 'fraction at' is used as the preferred minimum wage variable.

\section{Data and descriptive statistics}

The datasets used in this article, come from the National Survey of Employment and Unemployment (ENEMDU), collected by the Ecuadorian National Institute of Statistics and Census (INEC). The surveys are designed as rotating panels under the scheme 2-2-2; that is, households are interviewed for two consecutive quarters then, they are replaced by a new sample of households that are interview for the next two consecutive quarters, for finally entering the sample again for two last quarters before exiting the survey. The sample in renewed every two years.

The period of analysis includes the years 2000-12. Surveys correspond to the month of December of each year. Data is weighted by the Expansion factors provided by the INEC.

The sampling unit is a dwelling or housing structure. Information regarding the household or households occupying each dwelling is collected for each member of the household. Incomes reported in the surveys are gross of taxes, and they are disaggregated in

\footnotetext{
${ }^{2} 0.9$ and 1.1 are approximations in order to take into account measurement errors. Results are also robust for 0.95 and 1.05 .
} 
such a way that information regarding social benefits such as holiday bonus, and contributions to social security can be recovered. There are three sources of labor income: main job, secondary job, and other jobs; and different sources of non-labor income. The wage variable used in the estimation considers only the earnings of the main job.

Some adjustments are made to the original dataset. First, we consider workers aged between 15-70 years old. Second, public sector employees where withdrawn from the sample, since they follow a different wage setting. Third, individuals whose wage is situated below the first or above the 99th percentile were eliminated from the sample. Between 2000-12, this amount correspond in average to 3 per cent of the original sample of workers in the private sector aged 15-70 years old. Fourth, wages and other non labor incomes were deflated by the consumer price index of the corresponding month, according to the proper reference period. Finally, data was aggregated across Provinces in order to construct a cross-sectional/time series panel, where $\mathrm{N}=20$ and $\mathrm{T}=13$.

\subsection{Minimum wage}

Figure 1: Hourly minimum wage

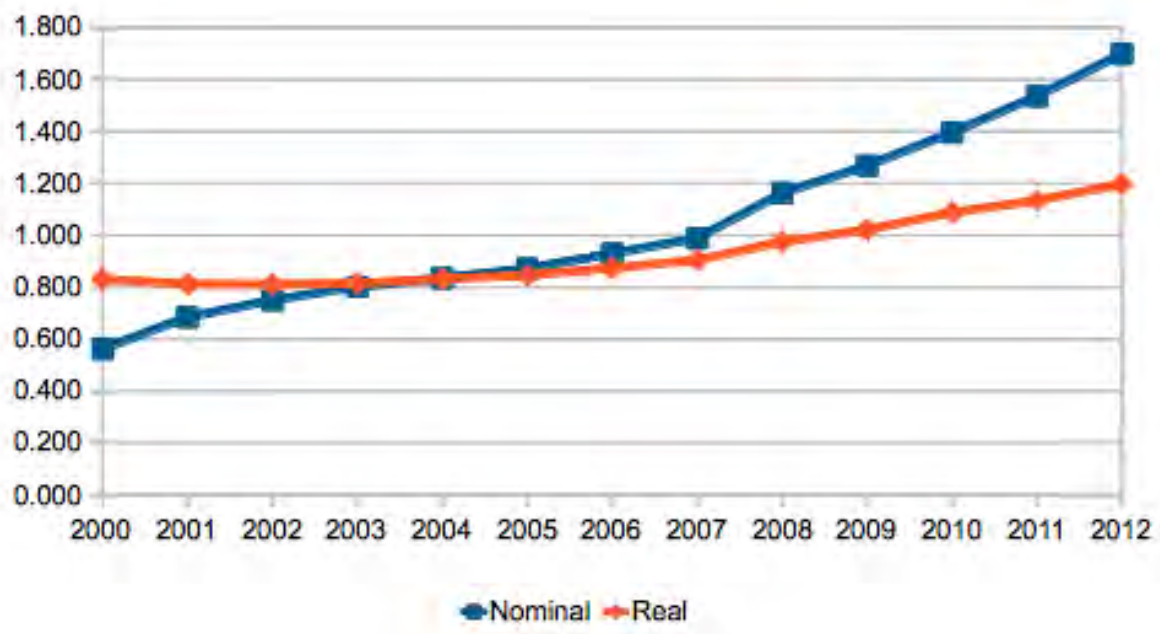

Source: Estimated from ENEMDU 2000-2012. 
Nominal wages data is collected by the Central Bank of Ecuador (BCE).

Figure 1 plots the nominal and the real wage between 2000-12. The period 1997-2000 was characterized by extremely high inflation, so there was a huge decline in nominal and real wages over this period.

Table 1 summarizes the evolution of wages and presents ratios of the minimum wages to different moments of the wage distribution. The first thing to notice is that averages market wages are higher than the legal minimum wage for all years except for 2000 . This was the year in which US dollar was adopted as local currency, so this explain the difference. Looking at the ratios of the minimum wage with respect to the median wage, the 25 th quartile and the 10th quintile of the distribution, it is evident that the wage gap in the country is important. In average, workers earn above the minimum wage, but those on the lowest tail of the distribution, 10 per cent of the wage earners, earn in average, 3.1 times less than the minimum wage. This value has a decreasing pattern over time, but it is still relatively high.

Table 1: Wage distributions

\begin{tabular}{ccccccc}
\hline & & & \multicolumn{5}{c}{ Minimum Wage / } \\
\cline { 4 - 7 } Year & Real MW & Real Wages & Mean & Median & 25th per. & 10th per. \\
\hline 2000 & 0.831 & 0.699 & 1.190 & 1.611 & 2.900 & 4.833 \\
2001 & 0.812 & 0.875 & 0.928 & 1.358 & 2.353 & 4.412 \\
2003 & 0.814 & 0.891 & 0.914 & 1.217 & 2.069 & 3.448 \\
2004 & 0.832 & 0.943 & 0.882 & 1.197 & 1.915 & 3.519 \\
2005 & 0.845 & 0.969 & 0.872 & 1.136 & 1.875 & 3.333 \\
2006 & 0.874 & 1.045 & 0.836 & 1.091 & 1.714 & 3.000 \\
2007 & 0.904 & 1.063 & 0.850 & 1.087 & 1.700 & 3.188 \\
2008 & 0.975 & 1.050 & 0.928 & 1.154 & 1.806 & 3.158 \\
2009 & 1.021 & 1.030 & 0.991 & 1.199 & 1.908 & 3.338 \\
2010 & 1.087 & 1.092 & 0.996 & 1.200 & 1.800 & 3.000 \\
2011 & 1.133 & 1.185 & 0.957 & 1.100 & 1.740 & 3.106 \\
2012 & 1.196 & 1.230 & 0.972 & 1.098 & 1.752 & 3.066 \\
\hline
\end{tabular}

Estimated from ENEMDU 2000-2012. Hourly wages, US dollars.

Table A.5 in the Appendix shows the ratio of the minimum wage with respect to mean wages of those with primary, secondary, and tertiary education. Results are consistent with those of Table 1 . Workers who have attained at most primary education earn in average 
less than the minimum wage. The fact that almost half of the population belongs to this category explains the difference on the ratio with respect to the 25th quartile and the 10th quintile of the distribution, and suggest that the dispersion in wages within categories is important.

\subsection{Informality definitions}

Various definitions of informality can be found in the literature. The International Labor Organization (ILO) (2002) defines an informal worker as 'one whose labor relationship is not subject to labor legislation and tax rules, and has no access to social protection or right to certain labor benefits.' A second definition from the ILO considers informal workers all individuals who work in firms with five or fewer employees, do not have a university education, or are self-employed. Definitions based on whether the worker is self-employed or not, is a salaried worker in a small private firm, is a zero-income worker, or is not covered by social security system, are commonly found in the literature, see for instance Maloney and Nuñez Mendez [2003], Gindling and Terrell [2005], and Gasparini and Tornarolli [2009].

In this article three definitions are used. The first definition of informality includes all non-salaried workers (independent and self-employed) in the labor force. The second one is based on social security coverage. In Ecuador social security affiliation is mandatory for all workers, so if the worker is not affiliated to the system, most probably he/she does not receive mandated benefits either. All workers (whether they are salaried or not) who are not covered by social security, are considered informal. The third one defines informal workers as all salaried workers employed by small firms with less than five employees, plus all independent and self-employed workers. Since small firms are not subject to control, mandated benefits and social security coverage are usually not applied to workers in these firms.

It is my belief that definition 2 , based on social security coverage, gives a clearer picture of the proportion of informal workers in the labor market. First, by grouping formal and informal workers under this definition, one can be sure about the proportion of workers that will have the right to pension when retired, but also about the proportion of 
workers who receive the rest of mandated benefits, such as the teen salaries. Moreover, as MacIsaac and Rama [1997] pointed out, more than 80 per cent of those who receive teen salaries are affiliated with social security and have a written contract, which also assure compliance with tax system, at least for job earnings.

Figure 2 plots the informality rates based on the above definitions over time, while Figure 15, on the Appendix, plots the evolution of the employment, formality, and informality rate based on social security coverage definition, for each province in the dataset.

Figure 2: Informality definitions

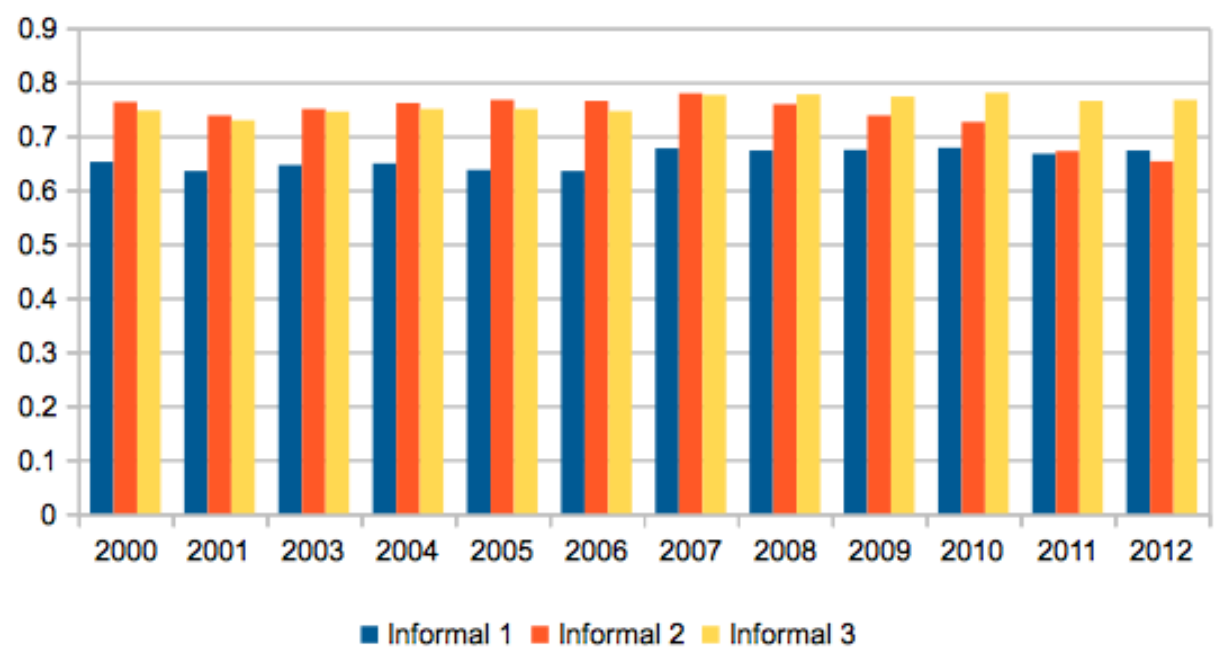

Source: Estimated from ENEMDU 2000-2012.

\subsection{Who are the informal workers?}

Tables A.2 and A.3 in the Appendix, summarize the main characteristics of the labor force in Ecuador over time, for the three definitions of formality and informality rates. In average an informal worker earn less than one in the formal sector, no matter the definition used. 
Workers with secondary educations dominate both, the formal and the informal sector which can explain the dispersion in wages, but the share of workers with tertiary education is more than double in the formal sector compared to the informal one.

In general, in Ecuador as in most Latin American countries, the share of informal workers accounts for 50-80 per cent of the labor force. Among the common characteristics are the concentration of low skilled workers with low education levels, and the lack of social security coverage. These aspects along with the low level of wages suggest that most of the jobs in this sector are precarious, and that the incidence of poverty is high.

Table 2: Wage distributions

\begin{tabular}{ccccccc}
\hline & \multicolumn{5}{c}{ Minimum Wage / Mean Wage } \\
\cline { 2 - 7 } Year & Formal & Informal & Formal & Informal & Formal & Informal \\
& Workers 1 & Workers 1 & Workers 2 & Workers 2 & Workers 3 & Workers 3 \\
\hline 2000 & 1.11 & 1.24 & 0.89 & 1.30 & 0.94 & 1.29 \\
2001 & 0.86 & 0.97 & 0.71 & 1.01 & 0.70 & 1.03 \\
2003 & 0.78 & 0.98 & 0.70 & 0.98 & 0.67 & 1.00 \\
2004 & 0.77 & 0.95 & 0.69 & 0.94 & 0.65 & 0.97 \\
2005 & 0.76 & 0.94 & 0.66 & 0.94 & 0.65 & 0.95 \\
2006 & 0.74 & 0.89 & 0.66 & 0.89 & 0.62 & 0.91 \\
2007 & 0.73 & 0.93 & 0.66 & 0.91 & 0.62 & 0.95 \\
2008 & 0.80 & 1.01 & 0.71 & 1.01 & 0.68 & 1.02 \\
2009 & 0.83 & 1.09 & 0.77 & 1.08 & 0.73 & 1.09 \\
2010 & 0.84 & 1.09 & 0.79 & 1.09 & 0.74 & 1.09 \\
2011 & 0.79 & 1.07 & 0.77 & 1.08 & 0.71 & 1.07 \\
2012 & 0.80 & 1.09 & 0.79 & 1.10 & 0.72 & 1.09 \\
\hline
\end{tabular}

Estimated from ENEMDU 2000- 2012 surveys using sample weighted data. Based on hourly wages.

Table 2 presents the ratio of the minimum wage to averages wages for formal and informal workers and Table A.5 in the Appendix presents the averages wages in the formal and informal sectors by education level, for the three definitions used. The first thing to notice, is that formal workers do, in average, better than informal workers. Moreover, if we compare the results of the tables with the kernel density distributions of wages for both sectors, one can see that the dispersion of wages is high, and that the share of workers 
earning below the legal minimum wage is much more important than those who actually earn around it, but the gap in wages, in favor of those who earn the most, is important enough to bring the average wages near the minimum.

\section{Methodology}

\subsection{Effects on Employment}

Traditionally, the effect of the minimum wage on employment is modeled as follows:

$$
E_{i t}=\alpha+\beta \log M W_{i t}+\gamma X_{i t}+f_{i}+f_{t}+\epsilon_{i t}
$$

where $E_{i t}$ represents employment rate at province level. The equation is re-estimated with formality and informality rates as dependent variables. Minimum wage, $M W_{i t}$, is the variable of interest. As explained above it cannot be used directly on the estimation, so fraction at has been used instead of it. It is worth notice that the coefficient $\beta$ cannot be interpreted as an elasticity, since it actually measures the effect of a 1 per cent change on the fraction of workers earning near the MW, due to a change in the nominal minimum wage, on employment ${ }^{3}$.

Fixed effects, $f_{i}$ and $f_{t}$, are controlled with time and province dummies. They capture common macroeconomic effects, and provinces specific effects respectively. The set of control variables $X_{i t}$ also includes the size of the labor force, level of education, average hours worked, and average level of wages of those in the labor force.

There is a discussion on the literature of minimum wages regarding the inclusion of lags of the dependent variable in the right hand side of the equation in order to allow for non-contemporaneous adjustments in employment. Two main reasons for the noninclusion of the lagged variable are frequently found in the literature: first, minimum wage changes are usually announced in advance, which allows time for adjustment; second, voluntary turnover rates in low-wage labor markets are very high, so that a desired reduction in employment can be achieved quickly just by not replacing those who quit,

\footnotetext{
${ }^{3}$ Lemos [2004] proposes a way to calibrate the coefficients in order to interpret them as the percentage change in employment rate as a consequence of a 10 per cent increase in the nominal minimum wage.
} 
see Brown [1999]. Since the Ecuadorian labor market is characterized by high levels of informality (low wage workers) and noncompliance, and minimum wage changes take place every year, lagged variables are not included for the estimation of Equation $1^{4}$

Results are presented in levels and in differences. Time dummies and constant were included after differencing. The models were sample side weighted and the standard errors adjusted for clustering with the Stock and Watson correction in order to control for heteroskedasticity, specially the one coming from aggregation.

\subsection{Effects on wages}

A popular way to identify minimum wage effects on the distribution of wages that has become popular in the literature, is the inspection of the distribution through histograms and kernel density plots, see for instance the work of DiNardo et al. [1996], Bell [1997], Maloney and Nuñez Mendez [2003], Cunningham and Kristensen [2006], Lemos [2009], and Bhorat et al. [2013], among others. The intuition behind this method is that clustering around the minimum wage proves that it actually affects the wage distribution of workers. The plots also give an idea of the level of enforcement and coverage of the minimum wage.

In this article, kernel density plots are used, in a first stage, in order to have a visual idea of the evolution of wages of formal and informal workers separately, and to identify possible spikes in the distribution around the minimum wage.

The second stage consist on the econometric estimation of the following Equation:

$$
W_{i t}=\alpha+\beta \log M W_{i t}+\gamma X_{i t}+f_{i}+f_{t}+\epsilon_{i t},
$$

where $W_{i t}$ represents the average wage at province level. The set of controls is similar to the one used in Equation 1, with the inclusion of the share of workers in the manufacturing, agricultural, construction, retail, and transportation sectors, and the unemployment rate as extra variables.

\footnotetext{
${ }^{4}$ In the Ecuadorian case, the inclusion of the first lag of the employment rate did not change the results, moreover the lagged variable was not significantly different from zero. As pointed out by Brown [1999] this may due to the fact that the data is not rich enough to identify long-term responses if, indeed, they are different from the contemporaneous ones.
} 


\subsection{Robustness checks}

The results presented in the next section were estimated at national level. The models were also re-estimated for different subsamples, that is at urban level and for the group of workers that recorded working hours between 30-50 hours per week. Finally, a different range for the fraction of workers earning near the MW was also used. Results are similar in all of these cases.

\section{Results}

\subsection{Effects on employment}

Table 3 shows the results from the estimation of Equation 1 for the three definitions of formal and informal workers. Neoclassical theory predicts a negative effect of the minimum wage on employment rate, in particular in the formal sector. It does predicts, as well, an increase on the size of the informal sector. Contrary to what is expected from traditional theory, in the case of Ecuador, there is not evidence that increases in the minimum wage have a negative effect in the formal sector employment. The estimated coefficients are positive and significant (at 1 per cent), even though they are small.

As explained above, the models were re-estimated for urban workers only, and for workers (rural and urban) that recorded between 30-50 hours of work per week in their primary job. Results are robust to this, the sign and significant of the coefficients remain the same.

Table 3: Minimum wage - employment

\begin{tabular}{lcccccc}
\hline Fraction at & Formal 1 & Formal 2 & Formal 3 & Informal 1 & Informal 2 & Informal3 \\
\hline Levels & $0.979 * * *$ & $1.856^{* * *}$ & $0.944 * * *$ & $0.446 * * *$ & 0.190 & 0.105 \\
First Difference & $1.052^{* * *}$ & 0.498 & $0.870^{* * *}$ & $0.480^{* * *}$ & 0.037 & -0.061 \\
\hline \hline
\end{tabular}

Estimated from ENEMDU 2000- 2012 surveys using sample weighted data. $* \mathrm{p}<0.05, * * \mathrm{p}<0.01, * * * \mathrm{p}<0.001$. 
Results are also in line with prior evidence in the literature Card and Krueger [1994], Dickens et al. [1999], although the small size of the coefficients is closer to those found by Lemos [2009] in the Brazilian case.

A natural explanation for the non-negative employment effects in the country, is the high level of noncompliance. Even when in average formal workers earn above the minimum wage, there is still a significant proportion that earn below it. The ecuadorian laws do not contemplate unemployment subsidies, so individuals cannot afford to be out of employment, which also explains the high level of informality. Moreover, information regarding labor rights has become widespread in the last years, before 2008, individuals were more likely to accept jobs in the formal sector without proper knowledge of the mandated benefits that they were supposed to received, which also facilitated noncompliance from the employers part.

Tables A.6 and A.7 in the Appendix show the complete estimation results for the three definitions of formality and informality.

\subsection{Effects on wages}

The figures in the Appendix plot kernel density estimates of the wage distribution in Ecuador for the second definition of formal and informal workers separately. A vertical line shows the level of the minimum wage during the specific year.

The first thing to notice is the high level of noncompliance, in both, the formal and the informal sectors. It is, of course, more important in the informal sector where mandated benefits and regulations, by definition, do not apply. This can explain the absence of significant spikes around the minima, which is surprising if compared with common results in Latin American countries, see Bell [1997], Maloney and Nuñez Mendez [2003], and Lemos [2009].

If the minimum wage is effective, one should observe clustering of wages around it. From Table 1 we observe that mean and median wages are pretty close to the minimum wage level, and from the kernel densities we see that the distributions are somehow centered around it. However, over time the wage distribution of formal workers has shifted to the right, and the pick has passed to the right side of the minimum wage, even thought, it 
is not far from it. This may suggest that the shift to the right of the distribution maybe due to other macroeconomic variables and not to the presence of the minimum wage itself.

Kernel density estimates are very sensitive to the bandwidth choice ${ }^{5}$, so over smoothness of the distribution is possible. In order to correctly identify the effects of the minimum wage on the distribution of wages, the estimated coefficients of Equation 2 are presented underneath.

Table 4: Minimum wage-wages (levels)

\begin{tabular}{|c|c|c|c|c|}
\hline Log of Wages & Whole Sample & First Definition & Second Definition & Third Definition \\
\hline Fraction at & $\begin{array}{l}1.290 * \\
(0.55)\end{array}$ & & & \\
\hline Fraction at Formal & & $\begin{array}{l}0.902 \\
(0.52)\end{array}$ & $\begin{array}{l}0.351 \\
(0.74)\end{array}$ & $\begin{array}{l}0.735 \\
(0.85)\end{array}$ \\
\hline Fraction at Informal & & $\begin{array}{l}1.458 * \\
(0.63)\end{array}$ & $\begin{array}{c}1.664 * * \\
(0.54)\end{array}$ & $\begin{array}{l}1.418^{*} \\
(0.56)\end{array}$ \\
\hline
\end{tabular}

The first row of Table 4 shows the coefficient of fraction at defined over all workers, while the second and third row show the coefficients of fraction at defined over formal and informal workers separately. From the first estimation, one can see that the minimum wage has a positive effect on the distribution of wages, which is significant at 5 per cent. When fraction at is split, we see that the positive effect comes from wages of informal workers, suggesting that a floor wage serves as a reference wage in the uncovered sector. Regarding formal workers, there is not significant evidence that the minimum wage affects the wage in the covered sector, since the coefficients for the three definitions are not significantly different from zero. This goes against the findings for other Latin American Countries, where changes on the minimum wage have a positive effect on wages for both, the formal and informal workers.

Table A.9 in the Appendix show the complete estimation results in levels and first difference for the three definitions of formality and informality, once the coefficient of

\footnotetext{
${ }^{5}$ Kernel density estimates are based on the Epanechnikov kernel, and the bandwidth obtained from the rule of thumb proposed by Silverman [1986].
} 
fraction at has been separated for formal and informal workers. Note that the coefficients of fraction at defined over informal workers, in the first difference specification, loss significance from 0.01 and 0.05 . to 0.1 .

\subsection{Conclusions}

This article studies the relationship between minimum wage and informality. In particular it investigates whether or not, and if so, to what extent changes in the minimum wage influence changes on the employment rate, in the formal and informal sectors, and the level of wages.

Results indicate that during the last decade, the repeated increases of the minimum wage have not destroyed jobs in the Ecuadorian labor market. Moreover, the expected results from the two-sectors model, that predicts destruction of jobs in the formal sector and formal workers going either to unemployment or to the informal sector, seem not to apply to the Ecuadorian case. Results are robust to different definitions of informality, and to the estimation for different subsamples of workers.

Concerning its effect on the wage distribution, the minimum wage seems to have a significant positive effect on the distribution of wages, even thought it is small. This positive effect comes from wages of informal workers, suggesting that a floor wage serves as a reference wage in the uncovered sector.

In general terms, the minimum wage has not negative effects on employment, but it does not have a big positive effect on wages either, so the primary aims behind the imposition of a minimum wage, which are to provide a decent standard of living to the population, reduce wage inequalities and poverty have not been attained. A significant number of workers earn below the imposed minimum. The high level of noncompliance and the important share of informality call for new policies and institutions concerned with the enforcement of labor regulations, and the design of social security systems and laws that protect informal workers. Policy interventions should be redirected towards the creation of jobs in the formal sector, the enforcement of the law, and the appropriate investment on education. 


\section{References}

Linda Bell. The Impact of Minimum Wages in Mexico and Colombia. Journal of Labor Economics, 15(3):102-35, July 1997.

Haroon Bhorat, Ravi Kanbur, and Natasha Mayet. The Impact of Sectoral Minimum Wage Laws on Employment, Wages, and Hours of Work in South Africa. IZA Journal of Labor $\mathcal{E}$ Development, 2(1):1-27, 2013.

Mariano Bosch and Marco Manacorda. Minimum Wages and Earnings Inequality in Urban Mexico. American Economic Journal: Applied Economics, 2(4):128-49, 2010.

Charles Brown. Minimum Wages, Employment, and the Distribution of Income, volume 3 of Handbook of Labor Economics. Elsevier, 1999.

Charles Brown, Curtis Gilroy, and Andrew Kohen. The effect of the minimum wage on employment and unemployment: A survey. Journal of Economic Literature, 20(2): 487-528, Jun 1982.

Richard V Burkhauser, Kenneth A Couch, and David C Wittenburg. A Reassessment of the New Economics of the Minimum Wage Literature with Monthly Data from the Current Population Survey. Journal of Labor Economics, 18(4):653-80, October 2000.

David Card. Do Minimum Wages Reduce Employment? A Case Study of California. Industrial and Labor Relations Review, 46:38-54, 1992.

David Card and Alan B Krueger. Minimum Wages and Employment: A Case Study of the Fast-Food Industry in New Jersey and Pennsylvania. American Economic Review, 84 (5):772-793, September 1994.

Wendy Cunningham and Nicolai Kristensen. Do Minimum Wages In Latin America And The Caribbean Matter ? Evidence From 19 Countries. World Bank Policy Research Working Paper, 2006. 
Donald Deere, Kevin M Murphy, and Finis Welch. Employment and the 1990-1991 Minimum-Wage HikeWage Hike. American Economic Review Papers and Proceedings, 85(2):232-237, May 1995.

Richard Dickens and Alan Manning. Has the National Minimum Wage Reduced UK Wage Inequality? Journal of the Royal Statistical Society Series A, 167(4):613-626, 2004.

Richard Dickens, Stephen Machin, and Alan Manning. The Effects of Minimum Wages on Employment: Theory and Evidence from Britain. Journal of Labor Economics, 17 (1):1-22, 1999.

John DiNardo, Nicole M Fortin, and Thomas Lemieux. Labor Market Institutions and the Distribution of Wages, 1973-1992: A Semiparametric Approach. Econometrica, 64(5): 1001-44, September 1996.

Juan José Dolado, F. Kramarz, A. Manning, and S. Machin. The Economic Impact of Minimum Wages in Europe. Economic Policy, 11(23):317-372, 1996.

Pablo Fajnzylber. Minimum Wage Effects Throughout the Wage Distribution: Evidence from Brazil's Formal and Informal Sectors. Textos para Discussão Cedeplar-UFMG, 2001.

Leonardo Gasparini and Leopoldo Tornarolli. Labor Informality in Latin America and the Caribbean: Patterns and Trends from Household Survey Microdata. Desarrollo y Sociedad, pages 13-80, 2009.

T.H. Gindling and Katherine Terrell. The Effect of Minimum Wages on Actual Wages in Formal and Informal Sectors in Costa Rica. World Development, 33(11):1905-1921, November 2005.

John R Harris and Michael P Todaro. Migration, Unemployment \& Development: A Two-Sector Analysis. American Economic Review, 60(1):126-142, March 1970.

Lawrence F. Katz and Alan B. Krueger. The Effect of the Minimum Wage on the Fast Food Industry. NBER Working Papers, 1992. 
Sara Lemos. Are Wage and Employment Effects Robust to Alternative Minimum Wage Variables. IZA Discussion Paper, 2004.

Sara Lemos. Minimum Wage Effects in a Developing Country. Labour Economics, 16(2): 224-237, April 2009.

Donna MacIsaac and Martin Rama. Determinants of Hourly Earnings in Ecuador: The Role of Labor Market Regulations. Journal of Labor Economics, 15(S3):136-165, 1997.

William Maloney and Jairo Nuñez Mendez. Measuring the Impact of Minimum Wages: Evidence from Latin America. NBER Working Paper, 2003.

jacob Mincer. Unemployment Effects of Minimum Wages. Journal of Political Economy, 84(4):87-104, August 1976.

Marcelo Neri, Gustavo Gonzaga, and José Márcio Camargo. Efeitos Informais do Salário Mínimo e Pobreza. Textos Para Discussão Department of Economics PUC-Rio, 1998.

David Neumark and William Wascher. Employment Effects of Minimum and Subminimum Wages: Panel Data on State Minimum Wage Laws. Industrial and Labor Relations Review, 1(46):55-81, October 1992.

Bernard Silverman. Density Estimation for Statistics and Data Analysis. Monographs on Statistics and Applied Probability. Chapman \& Hall, 1986. 


\section{Appendix A}

Table A.1: Descriptive statistics (population aged 15-70)

\begin{tabular}{|c|c|c|c|c|c|c|c|c|c|c|c|c|}
\hline Variable & 2000 & 2001 & 2003 & 2004 & 2005 & 2006 & 2007 & 2008 & 2009 & 2010 & 2011 & 2012 \\
\hline \multirow[t]{2}{*}{ Gender: Male } & 0.623 & 0.584 & 0.644 & 0.628 & 0.633 & 0.635 & 0.597 & 0.6 & 0.606 & 0.623 & 0.62 & 0.619 \\
\hline & $(0.485)$ & $(0.493)$ & $(0.479)$ & $(0.483)$ & $(0.482)$ & $(0.481)$ & $(0.491)$ & $(0.490)$ & $(0.489)$ & $(0.485)$ & $(0.485)$ & $(0.486)$ \\
\hline \multirow[t]{2}{*}{ Primary } & 0.562 & 0.542 & 0.574 & 0.58 & 0.564 & 0.546 & 0.548 & 0.538 & 0.538 & 0.529 & 0.497 & 0.489 \\
\hline & $(0.496)$ & $(0.498)$ & $(0.494)$ & $(0.494)$ & $(0.496)$ & $(0.498)$ & $(0.498)$ & (0.499) & $(0.499)$ & (0.499) & $(0.500)$ & $(0.500)$ \\
\hline \multirow[t]{2}{*}{ Secondary } & 0.323 & 0.329 & 0.315 & 0.302 & 0.32 & 0.331 & 0.33 & 0.336 & 0.34 & 0.346 & 0.358 & 0.369 \\
\hline & $(0.467)$ & $(0.470)$ & $(0.465)$ & $(0.459)$ & $(0.466)$ & $(0.471)$ & $(0.470)$ & $(0.472)$ & $(0.474)$ & $(0.476)$ & $(0.479)$ & $(0.483)$ \\
\hline \multirow[t]{2}{*}{ Tertiary } & 0.115 & 0.129 & 0.111 & 0.118 & 0.117 & 0.123 & 0.122 & 0.126 & 0.122 & 0.125 & 0.145 & 0.142 \\
\hline & $(0.319)$ & $(0.335)$ & $(0.314)$ & $(0.323)$ & $(0.321)$ & $(0.328)$ & $(0.327)$ & $(0.332)$ & $(0.327)$ & $(0.331)$ & $(0.352)$ & (0.349) \\
\hline \multirow[t]{2}{*}{ Urban } & 0.605 & 0.574 & 0.55 & 0.539 & 0.549 & 0.55 & 0.525 & 0.539 & 0.532 & 0.526 & 0.565 & 0.554 \\
\hline & $(0.489)$ & $(0.494)$ & $(0.497)$ & $(0.498)$ & $(0.498)$ & $(0.498)$ & $(0.499)$ & $(0.498)$ & $(0.499)$ & $(0.499)$ & $(0.496)$ & $(0.497)$ \\
\hline \multirow[t]{2}{*}{ Formal 1} & 0.281 & 0.282 & 0.263 & 0.28 & 0.291 & 0.297 & 0.276 & 0.274 & 0.267 & 0.273 & 0.291 & 0.286 \\
\hline & $(0.450)$ & $(0.450)$ & $(0.440)$ & $(0.449)$ & $(0.454)$ & $(0.457)$ & $(0.447)$ & $(0.446)$ & $(0.442)$ & $(0.445)$ & $(0.454)$ & $(0.452)$ \\
\hline \multirow[t]{2}{*}{ Informal 1} & 0.652 & 0.635 & 0.646 & 0.649 & 0.637 & 0.635 & 0.677 & 0.673 & 0.674 & 0.678 & 0.667 & 0.673 \\
\hline & $(0.476)$ & $(0.481)$ & $(0.478)$ & $(0.477)$ & $(0.481)$ & $(0.481)$ & $(0.468)$ & $(0.469)$ & $(0.469)$ & $(0.467)$ & $(0.471)$ & (0.469) \\
\hline \multirow[t]{2}{*}{ Formal 2} & 0.17 & 0.179 & 0.159 & 0.169 & 0.162 & 0.166 & 0.174 & 0.188 & 0.203 & 0.225 & 0.286 & 0.305 \\
\hline & $(0.376)$ & $(0.383)$ & $(0.366)$ & $(0.375)$ & $(0.368)$ & $(0.372)$ & $(0.379)$ & $(0.390)$ & $(0.402)$ & $(0.417)$ & $(0.452)$ & $(0.461)$ \\
\hline \multirow[t]{2}{*}{ Informal 2} & 0.763 & 0.738 & 0.75 & 0.761 & 0.767 & 0.765 & 0.779 & 0.759 & 0.738 & 0.726 & 0.672 & 0.653 \\
\hline & $(0.426)$ & $(0.440)$ & $(0.433)$ & $(0.427)$ & $(0.423)$ & $(0.424)$ & $(0.415)$ & $(0.428)$ & $(0.440)$ & $(0.446)$ & $(0.469)$ & $(0.476)$ \\
\hline \multirow[t]{2}{*}{ Formal 3} & 0.185 & 0.188 & 0.165 & 0.179 & 0.178 & 0.186 & 0.177 & 0.17 & 0.168 & 0.171 & 0.193 & 0.192 \\
\hline & $(0.389)$ & $(0.390)$ & $(0.371)$ & $(0.383)$ & $(0.383)$ & $(0.389)$ & $(0.382)$ & $(0.375)$ & $(0.374)$ & $(0.377)$ & $(0.395)$ & $(0.394)$ \\
\hline \multirow[t]{2}{*}{ Informal 3} & 0.747 & 0.729 & 0.745 & 0.75 & 0.75 & 0.746 & 0.776 & 0.777 & 0.773 & 0.78 & 0.765 & 0.767 \\
\hline & $(0.435)$ & $(0.444)$ & $(0.436)$ & $(0.433)$ & $(0.433)$ & $(0.435)$ & $(0.417)$ & $(0.416)$ & $(0.419)$ & $(0.415)$ & $(0.424)$ & $(0.423)$ \\
\hline \multirow[t]{2}{*}{ Unemployment } & 0.0672 & 0.0829 & 0.0902 & 0.0706 & 0.0712 & 0.0685 & 0.0469 & 0.0532 & 0.0594 & 0.049 & 0.042 & 0.0415 \\
\hline & $(0.250)$ & $(0.276)$ & $(0.286)$ & $(0.256)$ & $(0.257)$ & $(0.253)$ & $(0.211)$ & $(0.224)$ & $(0.236)$ & $(0.216)$ & $(0.201)$ & (0.199) \\
\hline \multirow[t]{2}{*}{ Fraction at } & 0.0664 & 0.0788 & 0.106 & 0.101 & 0.106 & 0.119 & 0.103 & 0.111 & 0.109 & 0.124 & 0.137 & 0.137 \\
\hline & $(0.249)$ & $(0.269)$ & $(0.308)$ & $(0.301)$ & $(0.308)$ & $(0.323)$ & $(0.304)$ & $(0.314)$ & $(0.311)$ & $(0.329)$ & $(0.343)$ & $(0.344)$ \\
\hline \multirow[t]{2}{*}{ Fraction below } & 0.741 & 0.667 & 0.569 & 0.543 & 0.534 & 0.503 & 0.58 & 0.606 & 0.615 & 0.608 & 0.556 & 0.567 \\
\hline & $(0.438)$ & $(0.471)$ & $(0.495)$ & $(0.498)$ & $(0.499)$ & $(0.500)$ & $(0.494)$ & $(0.489)$ & $(0.487)$ & $(0.488)$ & $(0.497)$ & $(0.495)$ \\
\hline \multirow[t]{2}{*}{ Agriculture } & 0.322 & 0.34 & 0.355 & 0.367 & 0.363 & 0.35 & 0.386 & 0.376 & 0.369 & 0.373 & 0.346 & 0.352 \\
\hline & $(0.467)$ & $(0.474)$ & $(0.479)$ & $(0.482)$ & $(0.481)$ & $(0.477)$ & $(0.487)$ & $(0.484)$ & $(0.482)$ & $(0.484)$ & $(0.476)$ & $(0.478)$ \\
\hline \multirow[t]{2}{*}{ Manufacturing } & 0.132 & 0.133 & 0.116 & 0.113 & 0.103 & 0.107 & 0.105 & 0.11 & 0.111 & 0.114 & 0.11 & 0.108 \\
\hline & $(0.339)$ & $(0.339)$ & $(0.320)$ & $(0.317)$ & $(0.304)$ & $(0.309)$ & $(0.306)$ & $(0.313)$ & $(0.314)$ & $(0.317)$ & $(0.313)$ & $(0.310)$ \\
\hline \multirow[t]{2}{*}{ Construction } & 0.0625 & 0.0556 & 0.0681 & 0.0667 & 0.0665 & 0.0726 & 0.0676 & 0.0712 & 0.0704 & 0.0692 & 0.069 & 0.0728 \\
\hline & $(0.242)$ & $(0.229)$ & $(0.252)$ & $(0.249)$ & $(0.249)$ & $(0.259)$ & $(0.251)$ & $(0.257)$ & $(0.256)$ & $(0.254)$ & $(0.254)$ & $(0.260)$ \\
\hline \multirow[t]{2}{*}{ Retail } & 0.211 & 0.196 & 0.187 & 0.188 & 0.188 & 0.192 & 0.183 & 0.18 & 0.19 & 0.19 & 0.208 & 0.2 \\
\hline & $(0.408)$ & $(0.397)$ & $(0.390)$ & $(0.391)$ & $(0.391)$ & $(0.394)$ & $(0.386)$ & $(0.384)$ & $(0.392)$ & $(0.392)$ & $(0.406)$ & $(0.400)$ \\
\hline \multirow[t]{2}{*}{ Transportation } & 0.0516 & 0.0454 & 0.051 & 0.0556 & 0.0575 & 0.0585 & 0.0551 & 0.0552 & 0.0576 & 0.0585 & 0.0628 & 0.0643 \\
\hline & $(0.221)$ & $(0.208)$ & $(0.220)$ & $(0.229)$ & $(0.233)$ & $(0.235)$ & $(0.228)$ & $(0.228)$ & $(0.233)$ & $(0.235)$ & $(0.243)$ & $(0.245)$ \\
\hline
\end{tabular}

Estimated from ENEMDU 2000-2012.Data shown as proportions. 
Table A.2: Descriptive statistics (informal wage earners aged 15-70)

\begin{tabular}{|c|c|c|c|c|c|c|c|c|c|c|}
\hline \multicolumn{11}{|c|}{ Informal 1} \\
\hline Year & Primary & Secondary & Tertiary & Male & Age 15-25 & Age $>60$ & Urban & Weekly Hours & $<30$ Hours & $>50$ Hours \\
\hline 2000 & 0.675 & 0.257 & 0.068 & 0.683 & 0.098 & 0.110 & 0.544 & 44.892 & 0.161 & 0.274 \\
\hline 2003 & 0.686 & 0.251 & 0.062 & 0.668 & 0.102 & 0.116 & 0.454 & 41.955 & 0.204 & 0.208 \\
\hline 2004 & 0.695 & 0.238 & 0.068 & 0.643 & 0.084 & 0.128 & 0.444 & 40.132 & 0.248 & 0.199 \\
\hline 2006 & 0.666 & 0.263 & 0.071 & 0.653 & 0.087 & 0.128 & 0.454 & 40.298 & 0.216 & 0.182 \\
\hline 2007 & 0.664 & 0.266 & 0.070 & 0.650 & 0.080 & 0.127 & 0.465 & 39.876 & 0.235 & 0.184 \\
\hline 2008 & 0.656 & 0.271 & 0.073 & 0.661 & 0.081 & 0.138 & 0.466 & 41.054 & 0.189 & 0.187 \\
\hline 2009 & 0.659 & 0.274 & 0.067 & 0.663 & 0.080 & 0.144 & 0.468 & 40.442 & 0.204 & 0.168 \\
\hline 2010 & 0.644 & 0.287 & 0.069 & 0.682 & 0.073 & 0.148 & 0.461 & 40.471 & 0.193 & 0.168 \\
\hline Year & Primary & Secondary & Tertiary & Male & Age 15-25 & Age $>60$ & Urban & Weekly Hours & $<30$ Hours & $>50$ Hours \\
\hline 2000 & 0.606 & 0.310 & 0.083 & 0.688 & 0.135 & 0.081 & 0.608 & 45.270 & 0.147 & 0.270 \\
\hline 2001 & 0.580 & 0.319 & 0.101 & 0.658 & 0.135 & 0.076 & 0.604 & 45.355 & 0.175 & 0.295 \\
\hline 2003 & 0.621 & 0.296 & 0.083 & 0.668 & 0.128 & 0.088 & 0.526 & 43.073 & 0.185 & 0.229 \\
\hline 2004 & 0.622 & 0.288 & 0.090 & 0.651 & 0.114 & 0.095 & 0.524 & 41.888 & 0.218 & 0.229 \\
\hline 2005 & 0.607 & 0.307 & 0.085 & 0.654 & 0.119 & 0.095 & 0.534 & 42.364 & 0.185 & 0.215 \\
\hline 2006 & 0.584 & 0.320 & 0.096 & 0.660 & 0.119 & 0.095 & 0.538 & 41.719 & 0.192 & 0.207 \\
\hline 2007 & 0.583 & 0.322 & 0.095 & 0.656 & 0.113 & 0.092 & 0.550 & 41.441 & 0.208 & 0.209 \\
\hline Year & Primary & Secondary & Tertiary & Male & Age 15-25 & Age $>60$ & Urban & Weekly Hours & $<30$ Hours & $>50$ Hours \\
\hline 2000 & 0.640 & 0.287 & 0.073 & 0.684 & 0.121 & 0.097 & 0.575 & 45.034 & 0.153 & 0.269 \\
\hline 2001 & 0.617 & 0.294 & 0.089 & 0.649 & 0.117 & 0.092 & 0.567 & 44.805 & 0.186 & 0.288 \\
\hline 2003 & 0.652 & 0.279 & 0.069 & 0.670 & 0.117 & 0.104 & 0.486 & 42.537 & 0.194 & 0.219 \\
\hline 2004 & 0.658 & 0.266 & 0.076 & 0.647 & 0.102 & 0.112 & 0.480 & 40.975 & 0.236 & 0.215 \\
\hline 2005 & 0.639 & 0.286 & 0.075 & 0.650 & 0.107 & 0.108 & 0.493 & 41.690 & 0.198 & 0.203 \\
\hline 2006 & 0.626 & 0.297 & 0.077 & 0.654 & 0.107 & 0.111 & 0.493 & 40.953 & 0.205 & 0.193 \\
\hline 2007 & 0.622 & 0.300 & 0.078 & 0.651 & 0.100 & 0.112 & 0.504 & 40.719 & 0.220 & 0.198 \\
\hline 2008 & 0.613 & 0.303 & 0.084 & 0.659 & 0.099 & 0.120 & 0.508 & 41.650 & 0.178 & 0.196 \\
\hline 2009 & 0.613 & 0.306 & 0.081 & 0.657 & 0.096 & 0.128 & 0.508 & 41.018 & 0.194 & 0.179 \\
\hline 2010 & 0.600 & 0.319 & 0.081 & 0.675 & 0.089 & 0.131 & 0.501 & 41.068 & 0.180 & 0.176 \\
\hline 2011 & 0.574 & 0.331 & 0.095 & 0.662 & 0.073 & 0.132 & 0.532 & 40.803 & 0.170 & 0.158 \\
\hline 2012 & 0.570 & 0.339 & 0.090 & 0.662 & 0.068 & 0.139 & 0.522 & 40.246 & 0.172 & 0.138 \\
\hline
\end{tabular}

Estimated from ENEMDU 2000-2012. Data shown as proportions. Weekly Hours: Average number of hours worked per week. 
Table A.3: Descriptive statistics (formal wage earners aged 15-70)

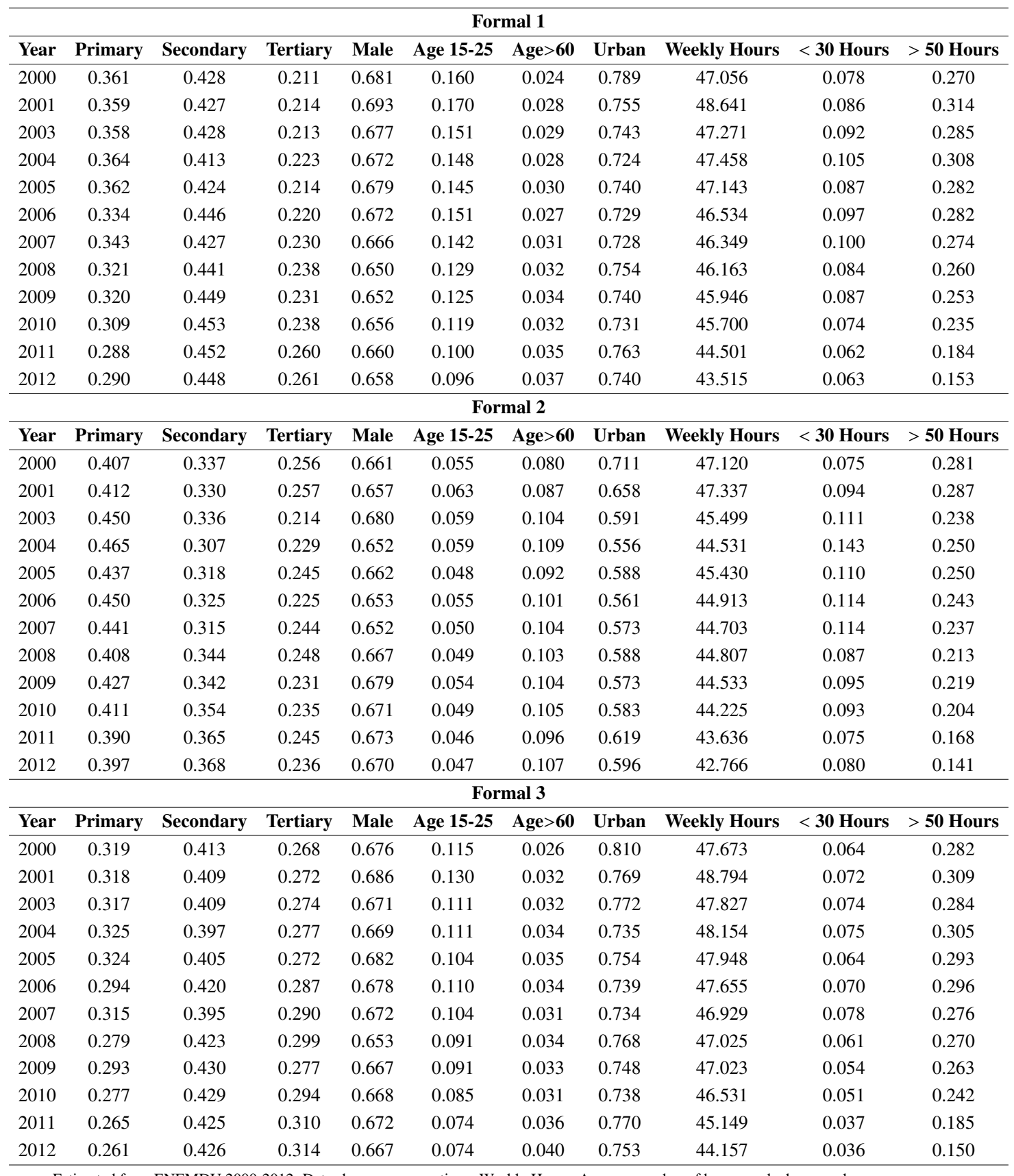

Estimated from ENEMDU 2000-2012. Data shown as proportions. Weekly Hours: Average number of hours worked per week. 
Table A.4: Wage distribution by sector and education level

\begin{tabular}{|c|c|c|c|c|c|c|c|c|}
\hline \multirow[b]{2}{*}{ Year } & \multicolumn{4}{|c|}{ Formal Workers 1} & \multicolumn{4}{|c|}{ Informal Workers 1} \\
\hline & Mean & Primary & Secondary & Tertiary & Mean & Primary & Secondary & Tertiary \\
\hline 2000 & 0.750 & 0.56 & 0.70 & 1.19 & 0.672 & 0.57 & 0.75 & 1.34 \\
\hline 2001 & 0.945 & 0.70 & 0.86 & 1.53 & 0.836 & 0.66 & 0.97 & 1.76 \\
\hline 2003 & 1.044 & 0.81 & 0.96 & 1.60 & 0.828 & 0.71 & 0.96 & 1.60 \\
\hline 2004 & 1.086 & 0.85 & 1.00 & 1.64 & 0.879 & 0.75 & 1.03 & 1.70 \\
\hline 2005 & 1.114 & 0.88 & 1.01 & 1.72 & 0.903 & 0.78 & 1.03 & 1.67 \\
\hline 2006 & 1.173 & 0.90 & 1.05 & 1.84 & 0.984 & 0.84 & 1.11 & 1.93 \\
\hline 2007 & 1.232 & 0.95 & 1.13 & 1.84 & 0.976 & 0.86 & 1.08 & 1.70 \\
\hline 2008 & 1.224 & 0.98 & 1.11 & 1.75 & 0.962 & 0.83 & 1.09 & 1.68 \\
\hline 2009 & 1.224 & 1.00 & 1.13 & 1.73 & 0.934 & 0.84 & 1.03 & 1.46 \\
\hline 2010 & 1.288 & 1.08 & 1.18 & 1.77 & 0.995 & 0.90 & 1.07 & 1.58 \\
\hline 2011 & 1.428 & 1.16 & 1.31 & 1.92 & 1.059 & 0.94 & 1.15 & 1.59 \\
\hline \multirow[t]{2}{*}{2012} & 1.499 & 1.26 & 1.40 & 1.94 & 1.093 & 0.99 & 1.16 & 1.65 \\
\hline & \multicolumn{4}{|c|}{ Formal Workers 2} & \multicolumn{4}{|c|}{ Informal Workers 2} \\
\hline Year & Mean & Primary & Secondary & Tertiary & Mean & Primary & Secondary & Tertiary \\
\hline 2000 & 0.938 & 0.65 & 0.91 & 1.42 & 0.640 & 0.56 & 0.68 & 1.11 \\
\hline 2001 & 1.146 & 0.77 & 1.10 & 1.81 & 0.806 & 0.65 & 0.87 & 1.52 \\
\hline 2003 & 1.165 & 0.83 & 1.13 & 1.91 & 0.832 & 0.71 & 0.92 & 1.43 \\
\hline 2004 & 1.200 & 0.80 & 1.22 & 1.99 & 0.885 & 0.76 & 0.97 & 1.48 \\
\hline 2005 & 1.286 & 0.90 & 1.23 & 2.05 & 0.902 & 0.78 & 0.98 & 1.48 \\
\hline 2006 & 1.318 & 0.90 & 1.32 & 2.15 & 0.985 & 0.84 & 1.03 & 1.74 \\
\hline 2007 & 1.365 & 0.94 & 1.36 & 2.15 & 0.991 & 0.87 & 1.04 & 1.57 \\
\hline 2008 & 1.371 & 0.98 & 1.33 & 2.07 & 0.966 & 0.84 & 1.04 & 1.49 \\
\hline 2009 & 1.328 & 1.00 & 1.31 & 1.95 & 0.943 & 0.84 & 1.00 & 1.38 \\
\hline 2010 & 1.370 & 1.05 & 1.33 & 2.00 & 0.997 & 0.91 & 1.04 & 1.43 \\
\hline 2011 & 1.479 & 1.12 & 1.46 & 2.07 & 1.047 & 0.94 & 1.10 & 1.47 \\
\hline \multirow[t]{2}{*}{2012} & 1.519 & 1.19 & 1.51 & 2.09 & 1.084 & 0.98 & 1.13 & 1.49 \\
\hline & \multicolumn{4}{|c|}{ Formal Workers 3} & \multicolumn{4}{|c|}{ Informal Workers 3} \\
\hline Year & Mean & Primary & Secondary & Tertiary & Mean & Primary & Secondary & Tertiary \\
\hline 2000 & 0.883 & 0.63 & 0.80 & 1.31 & 0.644 & 0.56 & 0.69 & 1.18 \\
\hline 2001 & 1.156 & 0.79 & 1.03 & 1.77 & 0.788 & 0.65 & 0.87 & 1.49 \\
\hline 2003 & 1.217 & 0.90 & 1.12 & 1.73 & 0.818 & 0.71 & 0.91 & 1.48 \\
\hline 2004 & 1.277 & 0.96 & 1.15 & 1.84 & 0.861 & 0.74 & 0.97 & 1.51 \\
\hline 2005 & 1.302 & 1.00 & 1.17 & 1.87 & 0.890 & 0.77 & 0.98 & 1.55 \\
\hline 2006 & 1.403 & 1.03 & 1.22 & 2.05 & 0.955 & 0.83 & 1.03 & 1.72 \\
\hline 2007 & 1.446 & 1.07 & 1.32 & 2.03 & 0.956 & 0.85 & 1.02 & 1.54 \\
\hline 2008 & 1.425 & 1.09 & 1.28 & 1.94 & 0.951 & 0.83 & 1.04 & 1.52 \\
\hline 2009 & 1.401 & 1.12 & 1.26 & 1.92 & 0.933 & 0.84 & 1.01 & 1.36 \\
\hline 2010 & 1.468 & 1.21 & 1.31 & 1.94 & 0.993 & 0.90 & 1.04 & 1.47 \\
\hline 2011 & 1.599 & 1.27 & 1.46 & 2.07 & 1.064 & 0.95 & 1.13 & 1.54 \\
\hline 2012 & 1.670 & 1.37 & 1.53 & 2.10 & 1.102 & 0.99 & 1.16 & 1.56 \\
\hline
\end{tabular}


Table A.5: Wage distribution by education level

\begin{tabular}{cccc}
\hline & \multicolumn{3}{c}{ Minimum Wage / } \\
\cline { 2 - 4 } Year & $\begin{array}{c}\text { Primary Edu. } \\
\text { Wage }\end{array}$ & $\begin{array}{c}\text { Secondary Edu. } \\
\text { Wage }\end{array}$ & $\begin{array}{c}\text { Tertiary Edu. } \\
\text { Wage }\end{array}$ \\
\hline 2000 & 1.46 & 1.14 & 0.67 \\
2001 & 1.22 & 0.89 & 0.50 \\
2003 & 1.12 & 0.85 & 0.51 \\
2004 & 1.08 & 0.82 & 0.50 \\
2005 & 1.06 & 0.83 & 0.50 \\
2006 & 1.03 & 0.81 & 0.47 \\
2007 & 1.03 & 0.82 & 0.51 \\
2008 & 1.13 & 0.89 & 0.57 \\
2009 & 1.17 & 0.95 & 0.63 \\
2010 & 1.16 & 0.98 & 0.64 \\
2011 & 1.15 & 0.93 & 0.63 \\
2012 & 1.15 & 0.95 & 0.65 \\
\hline
\end{tabular}

Estimated from ENEMDU 2000-2012. Based on hourly wages. 
Table A.6: Employment-fixed effects levels

\begin{tabular}{|c|c|c|c|c|c|c|}
\hline & Formal 1 & Formal 2 & Formal 3 & Informal 1 & Informal 2 & Informal3 \\
\hline Fraction at & $\begin{array}{c}0.979 * * * \\
(0.23)\end{array}$ & $\begin{array}{c}1.856^{* * * *} \\
(0.19)\end{array}$ & $\begin{array}{c}0.944 * * * \\
(0.17)\end{array}$ & $\begin{array}{c}0.446^{* * * *} \\
(0.07)\end{array}$ & $\begin{array}{l}0.190 \\
(0.26)\end{array}$ & $\begin{array}{l}0.105 \\
(0.15)\end{array}$ \\
\hline Age & $\begin{array}{l}-0.007 \\
(0.00)\end{array}$ & $\begin{array}{c}0.014 * \\
(0.01)\end{array}$ & $\begin{array}{l}0.001 \\
(0.00)\end{array}$ & $\begin{array}{c}0.009 * * \\
(0.00)\end{array}$ & $\begin{array}{l}-0.012 \\
(0.01)\end{array}$ & $\begin{array}{l}0.004 \\
(0.01)\end{array}$ \\
\hline Workers Aged $<60$ & $\begin{array}{l}0.062 \\
(0.18)\end{array}$ & $\begin{array}{l}-0.484 \\
(0.31)\end{array}$ & $\begin{array}{l}-0.047 \\
(0.13)\end{array}$ & $\begin{array}{l}0.264 \\
(0.17)\end{array}$ & $\begin{array}{l}0.765 * \\
(0.34)\end{array}$ & $\begin{array}{l}0.190 \\
(0.19)\end{array}$ \\
\hline Workers Aged 15-20 & $\begin{array}{c}-0.238 * \\
(0.10)\end{array}$ & $\begin{array}{l}0.142 \\
(0.15)\end{array}$ & $\begin{array}{l}-0.057 \\
(0.10)\end{array}$ & $\begin{array}{l}0.259 \\
(0.13)\end{array}$ & $\begin{array}{l}-0.106 \\
(0.15)\end{array}$ & $\begin{array}{l}0.155 \\
(0.15)\end{array}$ \\
\hline Urban & $\begin{array}{l}-0.028 \\
(0.03)\end{array}$ & $\begin{array}{c}-0.109 * \\
(0.04)\end{array}$ & $\begin{array}{l}-0.044 \\
(0.03)\end{array}$ & $\begin{array}{l}0.002 \\
(0.03)\end{array}$ & $\begin{array}{l}0.094 \\
(0.05)\end{array}$ & $\begin{array}{l}0.038 \\
(0.02)\end{array}$ \\
\hline Working Age Population & $\begin{array}{l}0.017 \\
(0.14)\end{array}$ & $\begin{array}{l}0.022 \\
(0.20)\end{array}$ & $\begin{array}{l}0.068 \\
(0.09)\end{array}$ & $\begin{array}{l}0.064 \\
(0.16)\end{array}$ & $\begin{array}{l}0.217 \\
(0.23)\end{array}$ & $\begin{array}{l}0.031 \\
(0.10)\end{array}$ \\
\hline Workers with Second Job & $\begin{array}{l}0.044 \\
(0.06)\end{array}$ & $\begin{array}{l}0.015 \\
(0.11)\end{array}$ & $\begin{array}{l}0.039 \\
(0.07)\end{array}$ & $\begin{array}{l}0.149 \\
(0.08)\end{array}$ & $\begin{array}{l}0.103 \\
(0.15)\end{array}$ & $\begin{array}{l}0.130 \\
(0.07)\end{array}$ \\
\hline Secondary & $\begin{array}{c}0.201 * * * \\
(0.04)\end{array}$ & $\begin{array}{c}0.261 * * \\
(0.08)\end{array}$ & $\begin{array}{l}0.148 \\
(0.07)\end{array}$ & $\begin{array}{c}-0.377 * * * \\
(0.04)\end{array}$ & $\begin{array}{c}-0.485^{* * *} \\
(0.10)\end{array}$ & $\begin{array}{c}-0.342 * * * \\
(0.05)\end{array}$ \\
\hline Tertiary & $\begin{array}{c}0.326^{* *} \\
(0.11)\end{array}$ & $\begin{array}{l}0.212 \\
(0.14)\end{array}$ & $\begin{array}{c}0.451 * * \\
(0.12)\end{array}$ & $\begin{array}{c}-0.280 * \\
(0.11)\end{array}$ & $\begin{array}{l}-0.277 \\
(0.16)\end{array}$ & $\begin{array}{c}-0.474 * * \\
(0.13)\end{array}$ \\
\hline Gender: Male & $\begin{array}{l}0.150 * \\
(0.07)\end{array}$ & $\begin{array}{l}0.134 \\
(0.09)\end{array}$ & $\begin{array}{l}0.056 \\
(0.06)\end{array}$ & $\begin{array}{l}0.010 \\
(0.06)\end{array}$ & $\begin{array}{l}-0.077 \\
(0.13)\end{array}$ & $\begin{array}{l}0.111 \\
(0.07)\end{array}$ \\
\hline Log of Wages & $\begin{array}{l}0.057 * \\
(0.02)\end{array}$ & $\begin{array}{l}-0.006 \\
(0.02)\end{array}$ & $\begin{array}{l}0.027 \\
(0.02)\end{array}$ & $\begin{array}{c}-0.095^{* *} \\
(0.03)\end{array}$ & $\begin{array}{l}-0.026 \\
(0.03)\end{array}$ & $\begin{array}{c}-0.048^{*} \\
(0.02)\end{array}$ \\
\hline Worked Hours & $\begin{array}{l}0.000 \\
(0.00)\end{array}$ & $\begin{array}{l}-0.000 \\
(0.00)\end{array}$ & $\begin{array}{l}0.000 \\
(0.00)\end{array}$ & $\begin{array}{l}-0.000 \\
(0.00)\end{array}$ & $\begin{array}{l}-0.000 \\
(0.00)\end{array}$ & $\begin{array}{r}-0.000 \\
(0.00)\end{array}$ \\
\hline Constant & $\begin{array}{c}0.320^{*} \\
(0.12)\end{array}$ & $\begin{array}{l}-0.463 \\
(0.28)\end{array}$ & $\begin{array}{l}-0.041 \\
(0.10)\end{array}$ & $\begin{array}{c}0.364 * \\
(0.17)\end{array}$ & $\begin{array}{c}1.192 * * * \\
(0.28)\end{array}$ & $\begin{array}{c}0.680^{*} \\
(0.26)\end{array}$ \\
\hline Time Dummies & Yes & Yes & Yes & Yes & Yes & Yes \\
\hline
\end{tabular}

Estimated from ENEMDU 2000- 2012 surveys using sample weighted data.

${ }^{*} \mathrm{p}<0.05,{ }^{* *} \mathrm{p}<0.01, * * * \mathrm{p}<0.001$. 
Table A.7: Employment-first difference

\begin{tabular}{|c|c|c|c|c|c|c|}
\hline & Formal 1 & Formal 2 & Formal 3 & Informal 1 & Informal 2 & Informal3 \\
\hline \multirow[t]{2}{*}{ Fraction at } & $1.052 * * *$ & 0.498 & $0.870^{* * *}$ & $0.480 * * *$ & 0.037 & -0.061 \\
\hline & $(0.19)$ & $(0.28)$ & $(0.19)$ & $(0.12)$ & $(0.19)$ & $(0.11)$ \\
\hline \multirow[t]{2}{*}{ Age } & -0.008 & $0.015^{* *}$ & 0.002 & $0.016^{* *}$ & -0.004 & 0.009 \\
\hline & $(0.01)$ & $(0.01)$ & $(0.00)$ & $(0.01)$ & $(0.01)$ & $(0.00)$ \\
\hline \multirow[t]{2}{*}{ Workers Aged $<60$} & 0.036 & -0.113 & 0.069 & 0.342 & 0.140 & -0.094 \\
\hline & $(0.25)$ & $(0.20)$ & $(0.20)$ & $(0.24)$ & $(0.29)$ & $(0.20)$ \\
\hline \multirow[t]{2}{*}{ Workers Aged 15-20 } & -0.289 & 0.041 & 0.023 & $0.408 * *$ & 0.102 & 0.146 \\
\hline & $(0.18)$ & $(0.17)$ & $(0.10)$ & $(0.15)$ & $(0.21)$ & $(0.15)$ \\
\hline \multirow[t]{2}{*}{ Urban } & 0.067 & $-0.161 *$ & 0.031 & $-0.190 *$ & 0.085 & $-0.137 *$ \\
\hline & $(0.09)$ & $(0.06)$ & $(0.04)$ & $(0.08)$ & $(0.07)$ & $(0.05)$ \\
\hline \multirow[t]{2}{*}{ Working Age Population } & 0.017 & 0.063 & -0.168 & -0.110 & -0.182 & 0.060 \\
\hline & $(0.18)$ & $(0.18)$ & $(0.16)$ & $(0.21)$ & $(0.23)$ & $(0.16)$ \\
\hline \multirow[t]{2}{*}{ Workers with Second Job } & 0.117 & 0.031 & 0.089 & 0.139 & 0.188 & $0.163^{*}$ \\
\hline & $(0.08)$ & $(0.09)$ & $(0.07)$ & $(0.09)$ & $(0.10)$ & $(0.08)$ \\
\hline \multirow[t]{2}{*}{ Secondary } & 0.123 & $0.251 * *$ & 0.076 & $-0.311 * * *$ & $-0.385 * * *$ & $-0.243 * * *$ \\
\hline & $(0.08)$ & $(0.09)$ & $(0.06)$ & $(0.07)$ & $(0.10)$ & $(0.07)$ \\
\hline \multirow[t]{2}{*}{ Tertiary } & $0.327 * *$ & $0.266^{*}$ & $0.368 * * *$ & -0.155 & -0.150 & $-0.263 *$ \\
\hline & $(0.11)$ & $(0.12)$ & $(0.09)$ & $(0.16)$ & $(0.15)$ & $(0.12)$ \\
\hline \multirow[t]{2}{*}{ Gender: Male } & $0.157 *$ & -0.026 & 0.093 & 0.006 & $0.222 *$ & 0.102 \\
\hline & $(0.07)$ & $(0.08)$ & $(0.05)$ & $(0.10)$ & $(0.10)$ & $(0.08)$ \\
\hline \multirow[t]{2}{*}{ Log of Wages } & $0.057 *$ & -0.005 & 0.019 & $-0.102 * * *$ & -0.021 & -0.039 \\
\hline & $(0.02)$ & $(0.02)$ & $(0.02)$ & $(0.02)$ & $(0.03)$ & $(0.02)$ \\
\hline \multirow[t]{2}{*}{ Worked Hours } & 0.000 & 0.000 & 0.000 & -0.000 & -0.000 & -0.000 \\
\hline & $(0.00)$ & $(0.00)$ & $(0.00)$ & $(0.00)$ & $(0.00)$ & $(0.00)$ \\
\hline \multirow[t]{2}{*}{ Constant } & -0.015 & 0.008 & -0.004 & -0.000 & -0.015 & -0.009 \\
\hline & $(0.01)$ & $(0.01)$ & $(0.01)$ & $(0.01)$ & $(0.01)$ & $(0.01)$ \\
\hline Time Dummies & Yes & Yes & Yes & Yes & Yes & Yes \\
\hline
\end{tabular}

Estimated from ENEMDU 2000- 2012 surveys using sample weighted data.

$* \mathrm{p}<0.05, * * \mathrm{p}<0.01, * * * \mathrm{p}<0.001$. 
Table A.8: Minimum wage-wages (levels)

\begin{tabular}{|c|c|c|c|}
\hline & First Definition & Second Definition & Third Definition \\
\hline \multirow[t]{2}{*}{ Fraction at Formals } & 0.902 & 0.351 & 0.735 \\
\hline & $(0.52)$ & $(0.74)$ & $(0.85)$ \\
\hline \multirow[t]{2}{*}{ Fraction at Informals } & $1.458 *$ & $1.664 * *$ & $1.418 *$ \\
\hline & $(0.63)$ & $(0.54)$ & $(0.56)$ \\
\hline \multirow[t]{2}{*}{ Unemployment Rate } & -0.191 & -0.275 & -0.194 \\
\hline & $(0.46)$ & $(0.45)$ & $(0.47)$ \\
\hline \multirow[t]{2}{*}{ Workers Aged $<60$} & -0.482 & -0.450 & -0.457 \\
\hline & $(0.53)$ & $(0.50)$ & $(0.51)$ \\
\hline \multirow[t]{2}{*}{ Workers Aged 15-20 } & $-1.083 * *$ & $-1.076^{* *}$ & $-1.088 * *$ \\
\hline & $(0.33)$ & $(0.35)$ & $(0.32)$ \\
\hline \multirow[t]{2}{*}{ Urban } & 0.189 & 0.166 & 0.172 \\
\hline & $(0.17)$ & $(0.18)$ & $(0.18)$ \\
\hline \multirow[t]{2}{*}{ Working Age Population } & $1.653 * *$ & $1.500 * *$ & $1.590 * *$ \\
\hline & $(0.45)$ & $(0.41)$ & $(0.41)$ \\
\hline \multirow[t]{2}{*}{ Secondary } & $-0.468 *$ & -0.449 & $-0.451 *$ \\
\hline & $(0.21)$ & $(0.23)$ & $(0.21)$ \\
\hline \multirow[t]{2}{*}{ Tertiary } & $1.055^{* *}$ & $1.105^{* *}$ & $1.087 * *$ \\
\hline & $(0.36)$ & $(0.35)$ & $(0.38)$ \\
\hline \multirow[t]{2}{*}{ Gender: Male } & $1.152 * * *$ & $1.199 * * *$ & $1.153 * * *$ \\
\hline & $(0.24)$ & $(0.25)$ & $(0.24)$ \\
\hline \multirow[t]{2}{*}{ Retail Sector } & $-0.779 *$ & $-0.795^{*}$ & $-0.741 *$ \\
\hline & $(0.36)$ & $(0.35)$ & $(0.34)$ \\
\hline \multirow[t]{2}{*}{ Manufacturing Sector } & -0.618 & -0.585 & -0.645 \\
\hline & $(0.52)$ & $(0.51)$ & $(0.52)$ \\
\hline \multirow[t]{2}{*}{ Agricultural Sector } & $-0.994 * * *$ & $-1.027 * * *$ & $-0.994 * * *$ \\
\hline & $(0.23)$ & $(0.25)$ & $(0.23)$ \\
\hline \multirow[t]{2}{*}{ Construction Sector } & -0.792 & -0.873 & -0.784 \\
\hline & $(0.53)$ & $(0.55)$ & $(0.53)$ \\
\hline \multirow[t]{2}{*}{ Transportation Sector } & 0.448 & 0.613 & 0.470 \\
\hline & $(0.69)$ & $(0.72)$ & $(0.70)$ \\
\hline \multirow[t]{2}{*}{ Constant } & $-1.863 * * *$ & $-1.770 * * *$ & $-1.821 * * *$ \\
\hline & $(0.30)$ & $(0.27)$ & $(0.27)$ \\
\hline Time Dummies & Yes & Yes & Yes \\
\hline
\end{tabular}

Estimated from ENEMDU 2000- 2012 surveys using sample weighted data.

$* \mathrm{p}<0.05, * * \mathrm{p}<0.01, * * * \mathrm{p}<0.001$. 
Table A.9: Minimum wage-wages (first difference)

\begin{tabular}{|c|c|c|c|}
\hline & First Definition & Second Definition & Third Definition \\
\hline \multirow[t]{2}{*}{ Fraction at Formals } & 0.645 & -0.240 & 0.342 \\
\hline & $(0.52)$ & $(0.73)$ & $(0.84)$ \\
\hline \multirow[t]{2}{*}{ Fraction at Informals } & 0.815 & 1.066 & 0.836 \\
\hline & $(0.49)$ & $(0.54)$ & $(0.46)$ \\
\hline \multirow[t]{2}{*}{ Unemployment Rate } & 0.005 & -0.004 & 0.016 \\
\hline & $(0.37)$ & $(0.37)$ & $(0.37)$ \\
\hline \multirow[t]{2}{*}{ Workers Aged $<60$} & 0.252 & 0.335 & 0.280 \\
\hline & $(0.81)$ & $(0.78)$ & $(0.79)$ \\
\hline \multirow[t]{2}{*}{ Workers Aged 15-20 } & $-1.050 * *$ & $-1.008 * *$ & $-1.049 * *$ \\
\hline & $(0.33)$ & $(0.33)$ & $(0.34)$ \\
\hline \multirow[t]{2}{*}{ Urban } & $-0.535^{*}$ & $-0.532 *$ & $-0.531^{*}$ \\
\hline & $(0.26)$ & $(0.26)$ & $(0.26)$ \\
\hline \multirow[t]{2}{*}{ Working Age Population } & 0.820 & 0.779 & 0.787 \\
\hline & $(0.73)$ & $(0.74)$ & $(0.73)$ \\
\hline \multirow[t]{2}{*}{ Secondary } & -0.512 & -0.552 & -0.499 \\
\hline & $(0.34)$ & $(0.32)$ & $(0.34)$ \\
\hline \multirow[t]{2}{*}{ Tertiary } & 0.819 & $0.819^{*}$ & $0.830^{*}$ \\
\hline & $(0.42)$ & $(0.41)$ & $(0.42)$ \\
\hline \multirow[t]{2}{*}{ Gender: Male } & $1.395 * * *$ & $1.397 * * *$ & $1.396 * * *$ \\
\hline & $(0.31)$ & $(0.31)$ & $(0.31)$ \\
\hline \multirow[t]{2}{*}{ Retail Sector } & $-1.286^{* *}$ & $-1.312 * *$ & $-1.259 * *$ \\
\hline & $(0.44)$ & $(0.44)$ & $(0.45)$ \\
\hline \multirow[t]{2}{*}{ Manufacturing Sector } & -0.917 & -0.853 & -0.920 \\
\hline & $(0.56)$ & $(0.56)$ & $(0.56)$ \\
\hline \multirow[t]{2}{*}{ Agricultural Sector } & $-1.566 * * *$ & $-1.590 * * *$ & $-1.560 * * *$ \\
\hline & $(0.38)$ & $(0.36)$ & $(0.38)$ \\
\hline \multirow[t]{2}{*}{ Construction Sector } & -1.023 & -1.137 & -1.023 \\
\hline & $(0.76)$ & $(0.73)$ & $(0.75)$ \\
\hline \multirow[t]{2}{*}{ Transportation Sector } & 0.270 & 0.352 & 0.278 \\
\hline & $(0.78)$ & $(0.78)$ & $(0.78)$ \\
\hline \multirow[t]{2}{*}{ Constant } & $0.212 * * *$ & $0.209 * * *$ & $0.213 * * *$ \\
\hline & $(0.04)$ & $(0.04)$ & $(0.04)$ \\
\hline Time Dummies & Yes & Yes & Yes \\
\hline
\end{tabular}

Estimated from ENEMDU 2000- 2012 surveys using sample weighted data.

$* \mathrm{p}<0.05, * * \mathrm{p}<0.01, * * * \mathrm{p}<0.001$. 
Figure 3: Log hourly real wage 2000

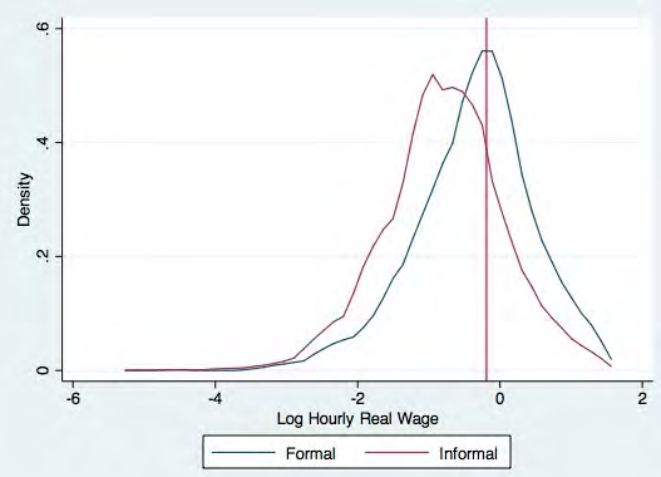

Figure 5: Log hourly real wage 2003

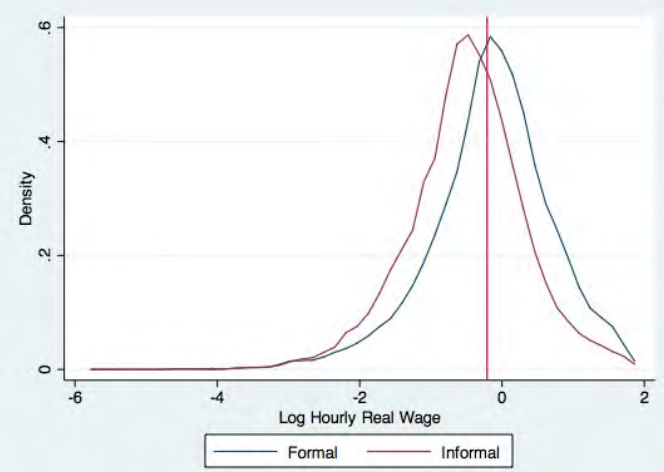

Figure 7: Log hourly real wage 2005

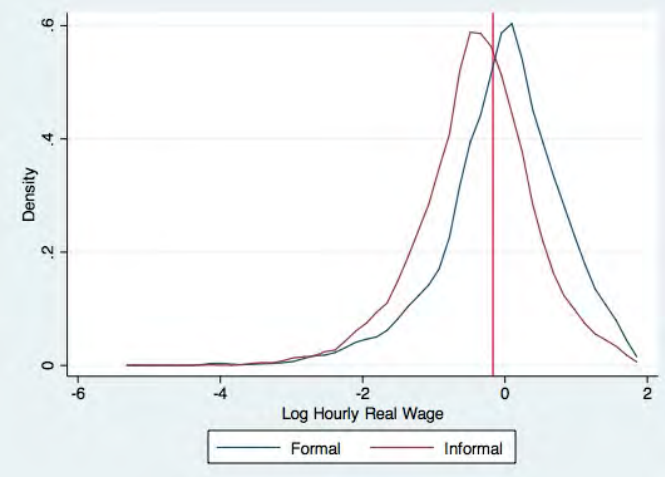

Figure 4: Log hourly real wage 2001

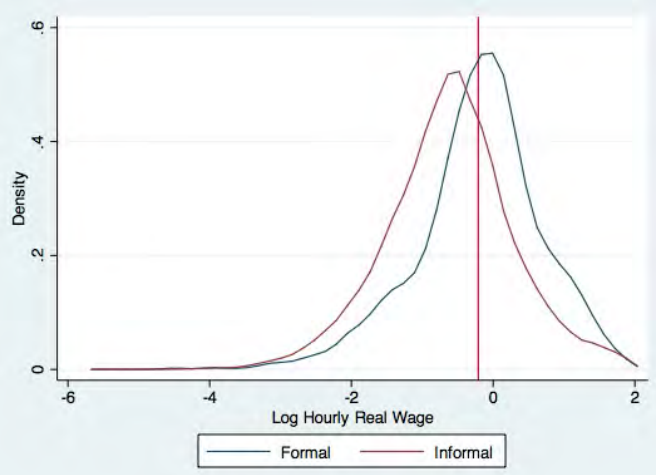

Figure 6: Log hourly real wage 2004

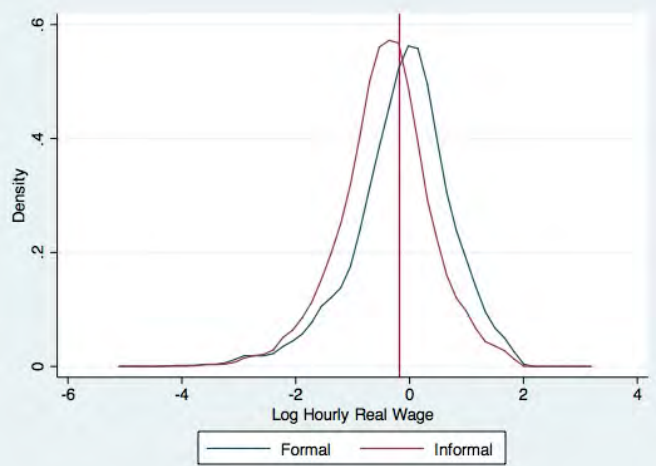

Figure 8: Log hourly real wage 2006

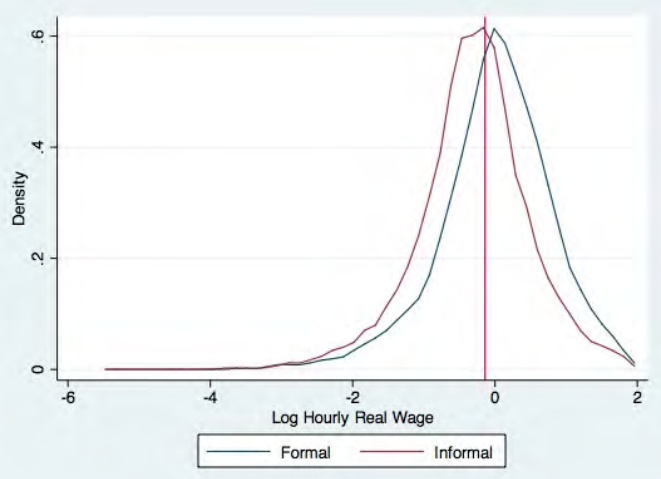

Source: Estimated from ENEMDU 2000- 2012 surveys using sample weighted data. 
Figure 9: Log hourly real wage 2007

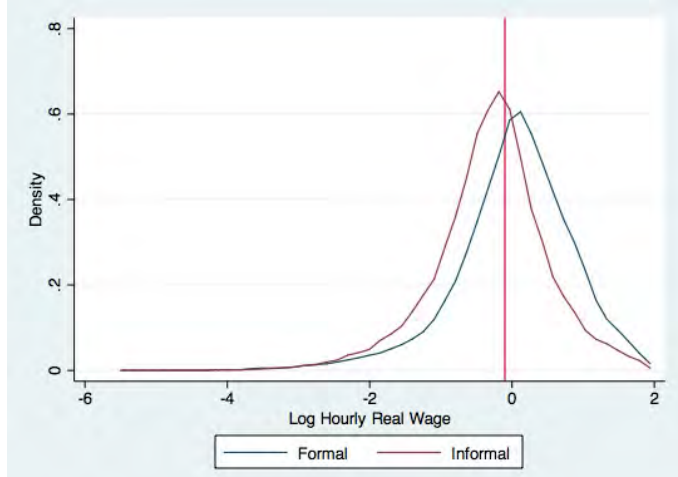

Figure 11: Log hourly real wage 2009

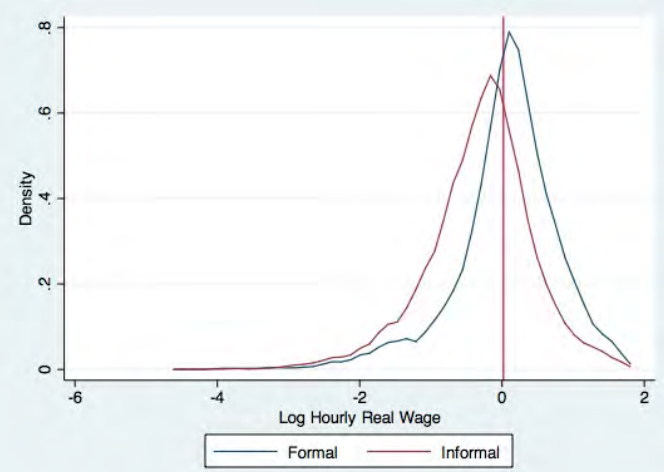

Figure 13: Log hourly real wage 2011

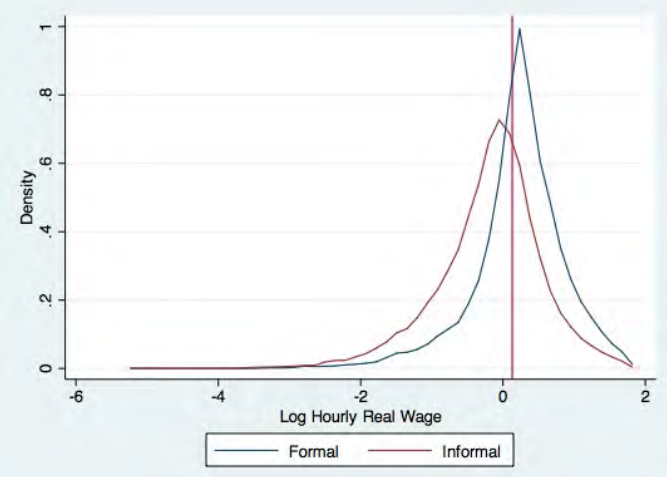

Figure 10: Log hourly real wage 2008

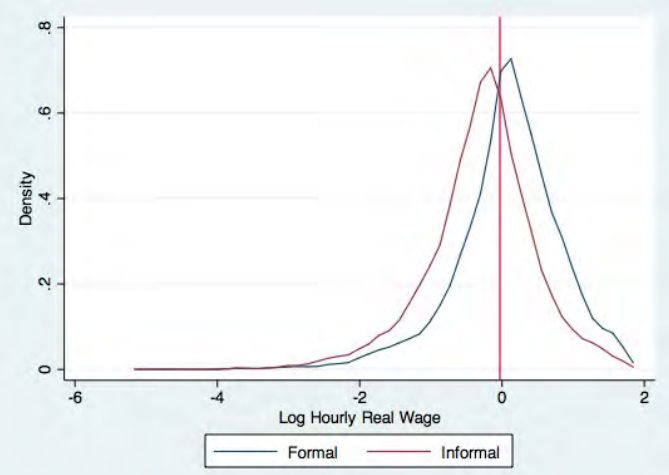

Figure 12: Log hourly real wage 2010

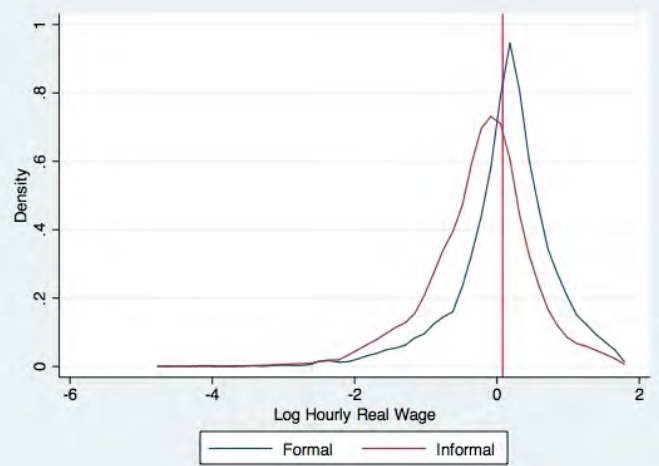

Figure 14: Log hourly real wage 2012

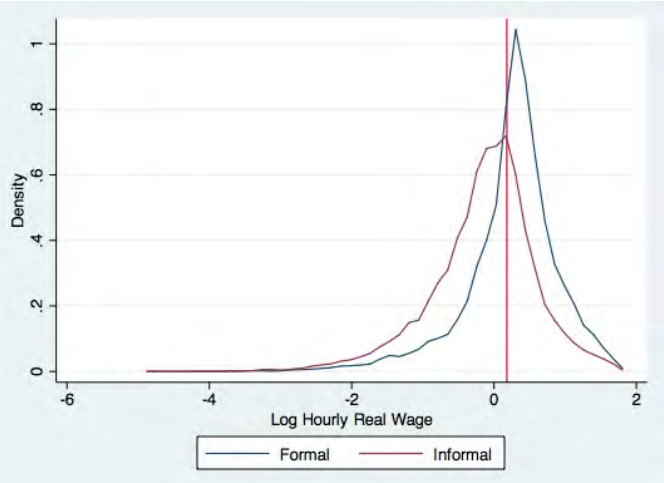

Source: Estimated from ENEMDU 2000- 2012 surveys using sample weighted data. 
Figure 15: Employment, formality, and informality rates by province

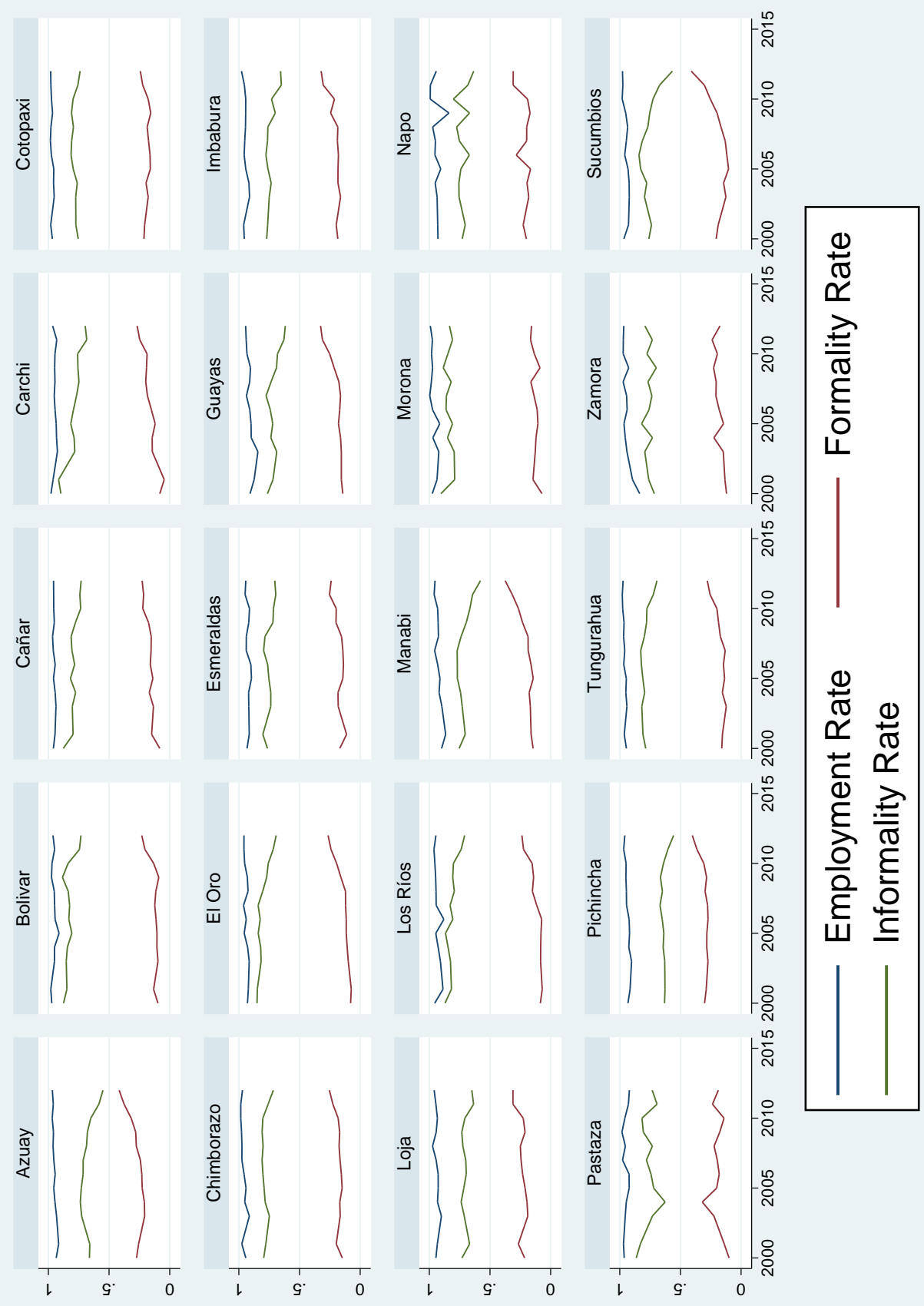

Source: Estimated from ENEMDU 2000- 2012 surveys using sample weighted data. 
Figure 16: Fraction of workers earning near the MW by province

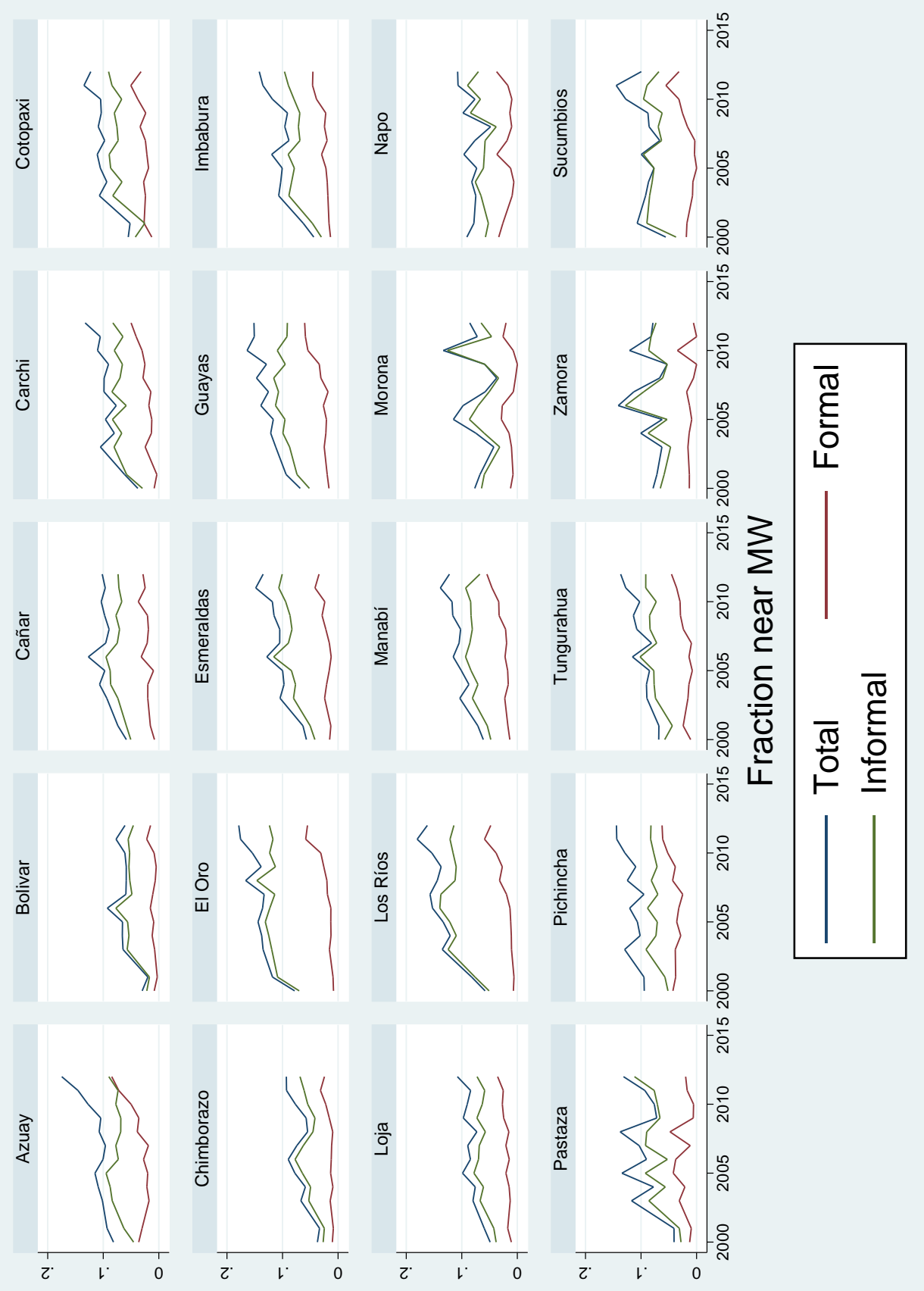

Source: Estimated from ENEMDU 2000- 2012 surveys using sample weighted data. 